\title{
Fear and Legitimacy in São Paulo, Brazil: \\ Police-Citizen Relations in a High Violence, High Fear City
}

Jonathan Jackson, London School of Economics \& Political Science and University of Sydney Law School

Krisztián Pósch, University College London

Thiago R. Oliveira, London School of Economics \& Political Science and Nuffield College, Oxford

Ben Bradford, University College London

Silvia M. Mendes, University of Minho

Ariadne Lima Natal, Núcleo de Estudos da Violência da Universidade de São Paulo

André Zanetic, Universidade Federal da Grandes Dourados

\begin{abstract}
We examine consensual and coercive police-citizen relations in São Paulo, Brazil. According to procedural justice theory, popular legitimacy operates as part of a virtuous circle, whereby normatively appropriate police behavior encourages people to self-regulate, which then reduces the need for coercive forms of social control. But can consensual and coercive police-citizen relations be so easily disentangled in a city in which many people fear crime, where the ability to use force can often be palpable in even mundane police-citizen interactions, where some people fear police but also tolerate extreme police violence, and where the image of the military police as "just another (violent) gang" has significant cultural currency? Legitimacy has two components - assent (ascribed right to power) and consent (conferred right to govern) - and consistent with prior work from the US, UK and Australia, we find that procedural justice is key to the legitimation of the police. Yet, the empirical link between legitimacy and legal compliance is complicated by ambivalent authority relations, rooted in part in heightened cultural expectations about police use of force to exercise power. We finish the paper with a discussion of the theoretical and policy implications of these findings.
\end{abstract}

Key words: Policing, legitimacy, Brazil, obligation to obey, compliance with the law, procedural justice, distributive justice, bounded authority, police violence.

The studies received financial support from the São Paulo Research Foundation (FAPESP) as part of the project "Building democracy daily: human rights, violence, and institutional trust” (CEPID-FAPESP 2013-07923-7).

This study was conducted in part by the Research Center in Political Science (UIDB/CPO/00758/2020), University of Minho, and was supported by the Portuguese Foundation for Science and Technology and the Portuguese Ministry of Education and Science through national funds. 
Brazil provides a context rather different to the liberal democracies in which research on police legitimacy and legal compliance has thus far been concentrated, such as the United States of America (Sunshine \& Tyler, 2003), the United Kingdom (Jackson et al., 2012) and Australia (Murphy et al., 2016). A range of social problems combine in a possibly unique way in Brazil to shape the relationship between individuals and state authorities, especially the police: low levels of trust in public institutions (Filgueiras, 2013); high crime rates and fear of crime (Cardia et al., 2014); the role of organized crime (something which is a particular issue in our study site of São Paulo, see Lessing and Willis, 2019); police violence and a relatively high level of public support (at least among some sections of society) for some of this violence (Caldeira, 2002). Brazil also stands somewhat apart from other Latin American countries in terms of crime, fear and trust. According to the Americas Barometer Survey fielded in 2016 and 2017, Brazil ranked $9^{\text {th }}$ out of 28 countries in terms of victimization but $3^{\text {rd }}$ in fear of crime. There is also a widespread feeling of unsafety and lack of protection. The same survey found that almost a quarter of the respondents reported feeling that their neighborhood was "very unsafe", and Brazilians had the least faith in their justice system, with almost 9 out of 10 respondents reporting little to no confidence that the judiciary will punish the guilty (Cohen et al., 2017).

In this paper we present one of the first empirical assessments of police legitimacy and legal compliance in Brazil (cf. Trinkner et al., 2020; Oliveira et al., 2020; and Zanetic, 2017). Drawing on data from two São Paulo-based surveys - one representative of eight neighborhoods chosen to reflect area-level diversity across the city, the other representative of the city population as a whole (see Appendix A for a descripton of the two surveys) - we test and extend procedural justice theory (PJT, Tyler, 2006a, 2006b) in a context in which the possibility of violence can be palpable even in relatively everyday police-citizen encounters (Lima et al., 2015). This is a city where people can fear both crime and police, where people may have instrumental and normative to both obey and disobey, and where popular legitimacy can combine with these factors to create a complex and sometimes ambivalent array of authority relations.

We find that the predictors of one component of legitimacy (the ascribed right to power) are consistent with work in settings like the US, UK and Australia-i.e. that a conceptualization of legitimation (the normative criteria that people use to judge the moral right to rule) based on procedural justice can be recovered even in a fearful, low trust policing environment like São Paulo. On this basis, "Western" values regarding the importance of fair process to legitimacy seem to translate to this particular city of the Global South. But contrary to prior work, we find that instrumental (coercive) and normative (consensual) police-citizen authority relations can be usefully framed along a single, coercive to consensual dimension (with ambivalent attitudes towards the police in the middle), not as the two distinct forms of authority relations traditionally conceived. Through our analysis of the composition, predictors and potential consequences of legitimacy - and its link to compliance with the law-we examine which aspects of PJT translate in São Paulo. Highlighting points of similarity and difference in a high violence, high fear setting, we reveal the complex nature of authority relations in this major city of the Global South.

\section{Literature review}

Scholars generally define popular police legitimacy (Tyler, 2006a, 2006b; for discussion, see Bottoms \& Tankebe, 2012; Tyler \& Jackson, 2013; Jackson \& Gau, 2016; and Trinkner, 2019) along two connected lines: first, the belief that the institution is moral, just and proper (assent); and second the belief that the officers who wield its power are morally entitled to enforce the law, make decisions, and expect people to willingly comply with rules and orders (consent). Legitimacy is seen as an ongoing dialogue between power-holders and subordinates (Bottoms \& Tankebe, 2012; cf. Martin \& Bradford, 2019). Through their day-to-day exercise of power, the object of legitimacy (police) continually makes claim to be just, proper and have the right to expect willing obedience and support, and those who are subject to that power continually assess and respond to those claims. Importantly, while citizens evaluate these claims according to locally specific normative expectations about how power should be exercised (Huq et al., 2017; Jackson, 2018; Jackson \& Bradford, 2019), PJT predicts that procedural justice is central to creating and maintaining the perceived right to rule, i.e. fair interpersonal treatment and decision-making are core normative expectations about the appropriate exercise of power. Legitimacy then motivates people to cooperate with the police and comply with the law because that's the right thing to do.

In contexts like the US and UK there is a good deal of evidence that procedural justice - the perceived fairness of legal procedures (Tyler \& Huo, 2002; Tyler \& Fagan, 2008) - is central to the 
process of legitimation (for an international review, see Jackson, 2018). When legal officials are seen and believed to make fair, balanced and accountable decisions and are seen and believed to treat people with respect, dignity, politeness and concern for their rights, this seems to help engender legitimacy in the eyes of those they police, serve and protect (Tyler, 2006a, 2006b; Trinkner \& Tyler, 2016; Tyler \& Trinkner, 2018). Recent work is also beginning to highlight the role played by police respecting the limits of their rightful authority (Huq et al., 2017; Tyler \& Trinkner, 2017; Trinkner et al., 2018), suggesting the relational importance of signaling not just status and value, but also respect for people's autonomy and agency (Bradford \& Jackson, 2021). Critically, effectiveness in the fight against crime and distributive justice (fair allocation of policing outcomes such as arrests, citations, protection, and service fairly across aggregate social groups) are typically less important predictors of legitimacy than perception of fair process and restrained use of power, particularly because they have less relational significance (Jackson et al., 2013a; Mazerolle et al., 2013; Bradford et al., 2014a; Mentovich et al., 2020).

Overall, the findings of studies from an increasing number of countries across the worldincluding the USA, Australia, Israel, UK, Hong Kong and Trinidad \& Tobago-support PJT's two core predictions: (a) that procedural justice is the most important normative expectation regarding the appropriate use of power, and (b) that police legitimacy is related to people's willingness to cooperate with legal authorities and comply with the law (for meta-analyses, see: Bolger \& Walters, 2019; Walters $\&$ Bolger, 2019). Legitimacy has also been shown to be a more important predictor of legal compliance than instrumental authority-relations based on perceptual deterrence, police effectiveness and fear of sanction on this matter (Papachristos et al., 2012; Jackson et al., 2012; Murphy et al., 2016; Trinkner et al., 2018), albeit we need more experimental data in this area of work (Nagin \& Telep, 2019; Tyler, 2019).

Yet, procedural justice may not be the central factor in the legitimation of legal authorities in each and every national context (Trinkner, 2019; Tyler, 2006: 384; Tyler \& Lind, 1992; Lind \& Tyler, 1988). Procedural justice is powerful, in part because authorities use it as a signalling device to confer group status and membership. As Tyler (1997: 325) says:

“...identity-based relational models predict that the extent to which people identify with groups will influence the basis of their judgments about authorities-with people who identify strongly with groups being more concerned about their treatment by authorities."

On this account, when individuals do not identify with the group an authority represents, or have little inclination to be a member, police legitimacy will be judged less on the basis of (relational) process (because fair process communicates positive status within the group) and more on the basis of instrumental outcomes (Lind \& Tyler, 1988; Tyler \& Lind, 1992).

There is emerging evidence that public concerns about effectiveness are at least as important to explaining variation in legitimacy as procedural justice in countries that have (a) high levels of crime, (b) legal institutions that have not yet been able to provide a bare minimum of security to citizens, (c) police with a long history of abuse of power, (d) authoritarian governments and state institutions, and/or (e) where people may tend not to identify so strongly with the group that the police represent. This is shown in research in South Africa (Bradford et al., 2014b), Pakistan (Jackson et al., 2014), Ghana (Tankebe, 2009) and China (Sun et al., 2017). In South Africa, for instance, Bradford et al. (2014b) suggest that normative judgements about fair process may to some degree be crowded out by concerns about police ineffectiveness and corruption, the sheer scale of the crime problem, and the association of the police with a historically oppressive and underperforming state.

In China, Sun et al. (2018: 276) argue that procedural justice may not be the most important source of legitimation, in part because "...the police in an authoritarian state are commonly empowered with excessive authorities that do not match normative expectations of democratic policing (e.g., procedural fairness, institutional transparency, and accountability)." Picking up this point, Trinkner (2019) argues that if people in South Africa or China are routinely sent signals that they are not a valued part of the social group that the police represent, or if the group that the police represent is not especially meaningful for most people, then procedural justice may not be so important to the legitimation of the police (Tyler \& Lind, 1992; Tyler, 1997). Factors like the fair allocation of resources and the effectiveness of behavior regulation among group members may come more to the fore, especially in contexts with high crime levels, police violence and corruption, and state authoritarianism. 


\section{Crime and policing in Brazil}

In light of the above, Brazil is a fascinating setting in which to explore police legitimacy and legitimation. In addition to the social issues already outlined, the history of the Brazilian police is entwined with the history of slavery. During the period of European colonization in South America, Brazil had the largest number of enslaved people for the longest period, and was the last country in the Americas to abolish slavery (in 1888). In an echo of the history of the southern United States, police throughout the period of slavery were essentially privately controlled by enslavers, and policing was targeted at enslaved people. However, abolition did not secure effective redress to the emancipated population, who experienced an incomplete and deficient form of citizenship (Huggins, 2000) characterized by high levels of dependence on the state, patrimonial-like relations with local powerholders and an absence of genuine civil rights (Schwarcz \& Starling, 2015).

Brazil also lived through an unstable twentieth century, shifting between dictatorship (1937-45 and 1964-85) and democratic rule. Even the democratic regimes had a de facto authoritarianism, with high levels of social control exerted over the marginalized poor and widespread political repression and illegal physical violence (Pinheiro 1991; Holstein 2008). Although the professionalization of the police was formally completed during the twentieth century (Batitucci, 2010), it remains associated with patrimonial power structures constituted by an overlap of the public and the private spheres. These relations are characterized by a power imbalance and significant social distance between a large excluded population and the State (dominated by a powerful minority).

More recently, a form of penal populism in Brazilian society is reflected partly by the expanding prison population; the per capita incarceration rate doubled between 2000 and 2014 (Iturralde, 2018). This punitive demand is matched by use of lethal force by the police (Anuário de Segurança Pública, 2017). Cases of excessive violence by the São Paulo Military Police are common. In 2018 alone, there were 6,160 confirmed police killings (Monitor da Violência, 2019 ${ }^{1}$ ), which is more than 25 times higher per capita than in the United States (The Guardian: The Counted) - and official statistics likely fall short of the real number (Willis, 2015). While it is impossible to ascertain the proportion of these killings that were illegal, nor fully document the extent of unreported cases of killings committed by officers, this is a large enough number to characterize police violence in São Paulo as a significant societal problem. The election of Jair Bolsonaro to the Brazilian presidency is a further confirmation of these tendenciesBolsonaro is a former army captain who speaks nostalgically about the 1964-1985 military dictatorship and has openly advocated police killings of criminals, promising iron-fisted policies and a crackdown on crime.

Within this context of multi-layered authoritarianism police remain highly militarized. Policing in each Brazilian state is carried out by two independent organizations: Military Police is responsible for day-to-day policing and order maintenance while Civilian Police, also known as the "judiciary police", comprise less than one third of overall numbers (Lima et al., 2016) and oversee crime registry and investigations. Military Police retains a particularly strong historical link to the period of slavery, indeed it has remained essentially the same organization since the nineteenth century, when its primary purpose was repressing insubordinate enslaved people (Batitucci, 2010). As all of its officers are part of the army reserve force, they must wear uniforms and carry weapons at all times, and their training and deployment involves a number of military features, e.g. strong hierarchical discipline.

The role and behavior of the police in Brazil suggests: (1) that the state does not guarantee an appropriate level of security for a significant portion of society and (2) that even when security is provided, social elites benefit more (Pereira and Ungar, 2004; González, 2017). The police are also more likely to use excessive force against people living in poor areas, who are more likely to be from racialized groups (Mitchell and Wood, 1999; Paes-Machado and Noronha, 2002; Goldstein, 2003; Garmany, 2014; Willis, 2015). Black residents seem to be less likely to be involved in community policing programs, which tend to be concentrated in middle-class and upper-middle-class areas (Alves, 2014). There is some evidence that elites and sections of the middle-class support police violence that seems to them to be directed at maintaining existing class, race and gender hierarchies. While they are unlikely to view the police in a favorable light, they are still supportive of state action that seeks to uphold the established order (Briceño-León et al., 1999).

Crucial to the current argument is that the relationship between police and the policed in Brazil may be marked by conflicting attitudes, including fear of being mistreated by the police but also relatively high levels of tolerance of - or at least ambivalence towards - excessive police violence against certain out-groups. Studies show that a fair amount of Brazilians distrust the police (Silva and Beato, 2013) and some fear them (Cardia et al., 2014), yet also that a considerable number do not 
necessarily condemn police violence when it is targeted at the marginalized and excluded (Garmany, 2014; Paes-Machado and Noronha, 2002; Caldeira, 2002; Briceño-León et al., 1999). There have also been calls in upper-middle-class neighborhoods to reinstate the edicts of the military dictatorship (González, 2017).

Moreover, even in relatively routine police-citizen encounters force may often be experienced by citizens as salient and 'present'. Almost half of all involuntary police-initiated encounters in São Paulo between 2015 and 2018 involved officers directly pointing a gun at the citizen (Oliveira (2021), and almost one in every five 14-year-olds living in São Paulo have witnessed police beating someone. While the ascribed right to use force is partly what defines legal authority in most Western contexts, in Brazil the state's ability to use force goes one step further and can be experienced and/or framed by many citizens as a concrete threat: police not only can but will use violence to exert power. This could be linked to a violent history: after centuries of colonialism and slavery and recent dictatorships (Schwarcz and Starling, 2015), it is plausible that the idea that violence is the only way to exert power has some widespread currency - in what Pinheiro (1991) labels a socially rooted authoritarianism.

São Paulo presents, then, a fractured social, political, and economic policing climate — at least compared to cities and countries in which PJT has thus far been tested. Police represent the proximate face of a paternalistic and authoritarian state, and low levels of trust may have had a negative impact on legitimation of the state and even satisfaction with the general idea of democracy (Filgueiras, 2013; González, 2017). Procedural justice may be less important to police legitimacy in São Paulo than factors like effectiveness and distributive justice, and people may have favorable attitudes towards 'excessive' police directed towards certain out-groups. Given that people may more readily associate power with the threat of violence (at least compared to some of the more traditional PJT research settings), fear of police and instrumental and normative reasons to obey and disobey may complicate the traditional conception of legitimacy and its link to compliance with the law. One might imagine police-citizen relations are relational for some, instrumental for others, but looking across the full population there could be considerable ambivalence.

How might PJT translate to Sāo Paolo in terms of normative versus instrumental motivations to comply with the law? In the two studies that make up this paper, we assess the construal of legitimacy and its potential antecedents and consequents, thereby contributing to the growing international literature on instrumental and normative authority relations. Examining whether PJT needs to adapt to the current context (and if so, how it needs to adapt), we address the criteria of legitimation in study one. Study two turns to the nature of instrumental and normative police-citizen relations and motivations to comply with the law.

\section{Study one: What legitimates the police in São Paulo?}

A starting premise of study one is that the content of legitimation-i.e. the bases on which popular legitimacy (which political philosophers might call empirical or descriptive legitimacy, e.g. Applbaum, 2019) is justified or contested through police activity in a given context - is something to be discovered through empirical research (Hough, 2020), not something to be imposed from the outside on the basis of political, moral, legal, religious or some other philosophy (Trinkner, 2019). If, for example, empirical work shows that procedural justice is the strongest (positive) predictor of legitimacy, then one can infer that procedural justice is an important dimension of appropriate (legitimate) police conduct, i.e. that procedural justice is a defining feature of what "appropriate, legitimating use of power" means in that specific setting.

At the threshold, it is important to say that this is an assumption (Jackson \& Bradford, 2019). It depends first on a conceptual analysis of legitimacy that marks off apt boundaries, and second on a well-reasoned operationalization strategy that allows researchers to judge the validity of the measures of the legitimacy construct. We draw on the idea of normative alignment, which holds that legitimacy is partly based on people's internalisation of the sentiment that Brinkmann (2020: 1203) calls - in his review of Applbaum's (2019) book Legitimacy: The Right to Rule in a Wanton World - 'we are ruling over you, but you are part of this we', i.e. that power is being exercised in ways that benefit and respect the interests, values and status of the group (Jackson et al., 2012, 2013a). We measure normative alignment using items that tap into the sense that police generally act in normatively appropriate ways, i.e. in ways that show respect for people's sense of how authority should be exercised on behalf of them and the group(s) they identify with (Huq et al., 2017).

By way of contribution, we draw on data from a survey of residents of eight different neighborhoods in São Paulo to test whether people's perceptions of police as a moral, just and 
appropriate institution - operationalized as normative alignment between police and citizen valuesare founded primarily in judgements of procedural justice, or whether São Paulo residents place greater emphasis on bounded authority (the restrained use of power), distributive justice (which we define as the fair allocation of outcomes, here the 'goods' and 'bads' of policing across diverse social groups) and effectiveness in the fight against crime. Given the context, it is also important to test whether those who tolerate 'excessive' violence against criminal out-groups also tend to view the police, who do sometimes use extreme violence against certain groups, as legitimate (and vice versa, whether those who are intolerant of such behavior tend to see the police as illegitimate). In the current paradigm, this means testing whether tolerance or intolerance of 'excessive' police violence predicts normative alignment, adjusting for procedural justice, distributive justice, effectiveness and bounded authority.

The first potential predictor of normative alignment is procedural justice. Definitions of procedural justice have evolved over the years, from Thibaut \& Walker's (1975) focus on process and outcome control in the allocation of resources, Leventhal's (1980) interest in people's perceptions of the fairness of allocative processes (decision accuracy, correctability, ethicality, representation, ability to suppress bias, and so forth),Tyler \& Folger's (1980) emphasis on more informal interactions between police and citizens, Tyler's (1988) inclusion of whether authorities are seen to act fairly and give the opportunity to correct errors, all the way up to the differentiation (e.g. Tyler \& Blader, 2000, 2003; Trinkner et al., 2018; for recent discussion, see Grootelaar \& Kees van den Bos, 2018; Solomon, 2019; Ansems et al. 2020) between fair interpersonal treatment (being treated with respect and dignity and believing that authorities have trustworthy motives) and fair decision-making (neutral, unbiased decision-making and having a voice in the interaction). Taking this most recent approach, we focus on police officers in their neighbourhood being seen to generally treat people with respect and dignity, make neutral decisions, and allow citizens the chance to give their 'side of the story'. This perspective puts the relational qualities of procedural justice center stage (Lind \& Tyler, 1988; Tyler \& Lind, 1992; Tyler, 1997) but we should note that our measurement strategy does not include trustworthy motiveswe want to put some 'clear conceptual water' between procedural justice and legitimacy (the appropriateness part of the legitimacy construct is sometimes operationalized as institutional trust, for discussion see Jackson \& Gau, 2016).

The second potential predictor of normative alignment is distributive justice. Distributive justice is generally defined in two ways: (a) perceptions of individual outcome fairness and deservingness (Tyler, 1990: 91; Tyler \& Blader, 2000; Solmon \& Cheane, 2021; and McLean 2020) and (b) perceptions of the fairness (or otherwise) of the allocation of the outcomes of exercised power - the 'goods' and 'impositions' of policing, both in the maintenance of social order and in the application of social control-across diverse social groups (Sunshine \& Tyler, 2003). We take the second approach (see Appendix B for further discussion). While studies in the US, UK and Australia have tended to find that distributive justice is a less important predictor of legitimacy than procedural justice, it is possible that distributive justice is an important legitimating factor in São Paulo, in part because of higher problem salience - after all, the police are perceived to act more aggressively in some neighborhoods than in others (Oliveira, 2021). Public concerns about the distributive justice of the police are relatively strong in São Paolo, with around two-thirds of research participants (63\%) in study two of the current paper saying that the police either 'never', 'rarely' or only 'sometimes' treated people equally. This compares to Tyler \& Jackson's (2014) national study of US citizens, where $45 \%$ said the police treated people differently according to their wealth, and $40 \%$ said the police treated people differently according to their ethnicity.

The third potential predictor of normative alignment is effectiveness in the fight against crime, measured here as dealing with drug dealing and armed robberies, investigating crime, keeping people safe, responding to emergency calls, and providing general crime-related services. As with distributive justice, effectiveness may be important to police legitimacy in São Paulo. On the one hand, levels of crime - and fear of crime - are relatively high. People may place special importance on the ability of the police to keep them safe when thinking about the justified use of power. On the other hand, perceived police effectiveness is relatively low. Some $42 \%$ of respondents in study two say they believe that local police are doing a good or very good job at responding to emergency calls, whereas Tyler \& Jackson (2014) found that $63 \%$ of their respondents thought that the police would arrive quickly if a violent crime were to occur in their neighborhood. As in South Africa-Bradford et al. (2014b) found only twofifths of people reported believing that the police would arrive quickly in an emergency-it may be that the police in São Paulo have not yet established the baseline, minimum ability to provide basic levels of 
security to citizens. This may raise the importance of police effectiveness in how people define the appropriate use of power.

The fourth potential predictor of normative alignment is bounded authority. Trinkner and colleagues (Trinkner et al., 2018; Huq et al., 2017; Trinkner \& Tyler, 2016; Tyler \& Trinkner, 2017) have argued that peoples' beliefs about the situations into which officers intrude, and the powers that officers exercise, represent an essential element of how they define and understand their relationship with police, like for instance how police power is legitimated in the eyes of citizens. We assess whether some individuals in São Paulo question whether the police are legitimate authorities when they believe that the police act as if they are above the law. In study two's city-wide representative survey, less than half of respondents said that the military police and the civil police ( $47 \%$ and $49 \%$ respectively) always or very often acted according to the law, while Tyler \& Jackson (2014) found that more than two-thirds of respondents $(68 \%)$ agreed or strongly agreed with the statement that 'when the police deal with people they almost always behave according to the law'.

The fifth (and final) potential predictor of normative alignment is perception of 'excessive' police violence (for discussion of the theoretical and empirical links between legitimacy and attitudes towards citizen and police violence, see Jackson et al., 2013b, Gerber \& Jackson, 2017, Bradford et al., 2017, and Gerber et al., 2018). People in São Paulo are aware that the police can use quite extreme violence in certain situations (González, 2017; Willis, 2015), and we presented study one participants with three scenarios, broadly based on actual cases that occurred in São Paulo in a few years prior to fieldwork that received extensive mass and social media coverage: disproportionate violence against protesters, the torture of a person in custody, and the murder of a suspect. Respondents were then asked what they thought about the officer behavior. Of particular interest is whether people who tolerate this kind of behavior (to foreshadow the results we find, for example, that just under one-quarter, $22 \%$, thought that the police torturing a drug dealer to get information was either 'good' or 'excellent') are more likely to believe that the police is a normatively appropriate institution (adjusting for perceptions of procedural justice \& distributive justice, effectiveness and bounded authority) compared to people who are intolerant (for whom one could infer that 'excessive' violence delegitimizes the police).

\section{Data, measures and analytical strategy}

Data come from the second wave of a three-wave longitudinal survey — designed and run by some of the current co-authors - that was representative of eight heterogeneous neighborhoods of São Paulo (for details see Nery et al., 2019, and Oliveira, 2021). The first wave was conducted in 2015, and 150 citizens in each of the eight areas were selected based on demographic quotas (gender, age, and education), producing a sample of 1,200 respondents. Because there was an attrition rate of $22.7 \%$, a total of 928 of those respondents took part in the second wave of the study in 2017 (see Appendix B for an assessment of attrition). We use the second wave because it contained the requisite variables needed to test the current predictions. All interviews were conducted face-to-face at the respondents' place, in Portuguese, using Tablet-Assisted Personal Interviewing (TAPI). Appendix B provides descriptive statistics and details of the measures.

Our analysis has three stages. First, we use confirmatory factor analysis (CFA) to assess the empirical distinctiveness and scaling properties of procedural justice, effectiveness, bounded authority (all measured using three indicators) and distributive justice (measured using a single indicator). Second, we use latent class analysis (LCA) to assess the underlying structure of people's responses to the three excessive police violence scenarios (see Appendix D for an explanation of why we prefer to represent the underlying latent quantity as categorical rather than continuous). In the LCA we test whether two, three or four classes best represent the data structure, we choose the model with the most appropriate fit, and we derive a variable based on modal probabilities for the next stage of analysis. We then use structural equation modeling (SEM) to estimate which factors most strongly predict normative alignment, which as mentioned earlier is how we operationalize the perceived moral right to exercise power (the first aspect of perceived police legitimacy).

\section{Results}

For the CFA, the approximate fit statistics suggest that the model fits the data adequately and that the scales work reasonably well (see Appendix C). For the LCA (see Appendix D), the modeling implies that there are three latent categories, with:

- $50 \%$ of research participants having mixed views about police use of force, albeit with a slight negative skew (the 'ambivalent' group); 
- $42 \%$ of research participants being strongly against it (the 'intolerant' group); and,

- $8 \%$ of research participants being supporters of excessive police use of force (the 'tolerant' group).

In preparation for the next stage of analysis, the most likely (i.e. expected) latent class membership was derived for each respondent given their scores on the various indicators $(50 \%$ 'ambivalent', $42 \%$ 'intolerant' and $8 \%$ 'tolerant').

Figure 1 reports the results of the fitted SEM, with normative alignment as the outcome variable and potential predictors being procedural justice, distributive justice, effectiveness, bounded authority and the two dummy variables for perceptions of police violence ("ambivalent towards police" and "intolerant of police violence", with "tolerance of police violence" as the reference category). The model also includes age, gender and each of the eight areas as controls (the coefficients for these variables are omitted for visual ease).

\section{INSERT FIGURE 1 ABOUT HERE}

Despite theoretical expectations derived from our reading of the social, political and legal context of São Paulo (set against prior work in Ghana, Pakistan, South Africa and China), our results are consistent with those from the US, UK and Australia (e.g. Tyler \& Fagan, 2008; Jackson et al., 2013a; Murphy et al., 2016). Specifically, procedural justice is the strongest positive predictor of normative alignment $(\beta=.81, \mathrm{p}<0.001)$. People who believed that officers tended to treat people with respect and dignity, make fair and neutral decisions, and listen to people and explain their decisions also tended to be normatively aligned with the police, adjusting for the other factors in the model. We infer from this that fair process is a strong interpersonal norm driving how officers should exercise their power. Effectiveness $(\beta=.12, p<0.001)$ is a relatively weak positive predictor and neither bounded authority $(\beta=.06, p=0.051)$ nor distributive justice $(\beta=.02, p=0.586)$ is statistically significant. Intolerance of and ambivalence towards 'excessive' police violence is unrelated to normative alignment in the fitted model, adjusting for the other factors ('intolerant' $\beta=-.01, p=0.727$, 'ambivalent' $\beta=.02$, $\mathrm{p}=0.484$ ). Of note, we also fitted a SEM without procedural justice, distributive justice, effectiveness and bounded authority, and found similar results ('intolerant' $\beta=.05, p=0.440$ and 'ambivalent' $\beta=.07$, $\mathrm{p}=0.226$ ).

On this basis, it seems that intolerance of 'excessive' police violence may not be a source of delegitimation in São Paulo. Compared to people who disapprove of police violence, those who tolerate or approve of police violence are not more or less likely to believe that officers generally act in normatively appropriate ways, adjusting for the other factors in the model. Distributive justice, effectiveness and bounded authority also explain little variance. Instead, our analysis suggests that procedural justice is the most important expectation about the appropriate use of power. It follows that the police need to treat people with respect, make fair decisions, and give people voice in interactions if they are to be seen to exercise their power appropriately. Nagin and Telep (2020) tie procedural justice closely to democratic principles, which are often used to describe Western societies. It seems that respectful and dignified treatment of citizens by the police is a presumptive and legitimating form of interaction in Brazil's largest city. We return to the implications of this for the international literature in the closing parts of this paper.

\section{Study two: Examining the nature of legitimacy and its link to legal compliance}

Study one focused on the first dimension of legitimacy, but addressing only the perceived right to power provides an incomplete picture. PJT positions legitimacy as both assent and consent. Legitimacy is not just the belief that the institution is moral, just and appropriate, it is also the acceptance of the right to expect deference, acceptance of decisions, and voluntary compliance. When officers conform to widely shared expectations about the appropriate use of power, people consent to the responsibilities associated with legal citizenship, not because of coercive, instrumental or other reasons, but because they glean value and identity from being respectful of rules and authority (Tyler, 1997; Tyler, 2006b; for discussion, see: Bottoms \& Tankebe, 2012; Tyler \& Jackson, 2013; Trinkner, 2019; Posch et al., 2020). They believe that following the instructions of legitimate authority and obeying the laws they enforce is the right and proper thing to do.

It is for this reason that duty to obey is often cited as the component or aspect of legitimacy most clearly motivational in character, especially when it comes to legal compliance (Tyler \& Jackson, 2013; Trinkner, 2019). So how does this translate in São Paulo?To address the importance of context 
for our understanding of the nature of legitimacy, and its connection to compliance with the law, our analysis proceeds in three steps.

\section{(1) Are there different motives to feel obligated to obey and disobey the police?}

Prior work in the US, UK, Australia and elsewhere measures obligation to obey using statements like 'I feel a moral obligation to obey the police', 'You should accept the decisions made by police, even if you think they are wrong', and 'You should obey police instructions because that is the proper or right thing to do'. When research participants agree with such statements, researchers assume that their answers reflect a normatively-grounded duty to obey. There are, however, other reasons why people may say they would obey the police, aside from what Posch et al. (2020) call "truly free consent". Bottoms and Tankebe (2012), Tankebe (2009: 1279-1281, 2013: 105-106) and Johnson et al., (2014: 970) argue that people could report an obligation (defining 'obligation' in a broader sense than Tyler; for discussion see Trinkner, 2019) to obey police for non-normative reasons, including pragmatism, dull compulsion, and fear of the consequences of non-compliance.

This may be especially relevant in a city like São Paulo, where there are high levels of police violence, malpractice, and corruption, where the threat to use force may be salient (perhaps even explicit) in even mundane interactions, and where police-community relations can be tense, conflictual and ambivalent, normative and non-normative forms of obligation may need disentangling. Some people might feel obligated to obey the police because they feel defiance is dangerous and/or that they have little choice to do anything but comply (Tankebe, 2009; Bottoms \& Tankebe, 2012; Johnson et al, 2014). Other people might feel a normative obligation to disobey the police (see for example Applbaum, 2019: 44-70) because they imagine the officer giving an immoral order; they might imagine police giving out illegitimate orders and view disobedience as an instance of moral protest. This references the boundary concerns that we investigated in study one-where people assess whether officers stray into spaces that they have no right to be - but in a situation where respondents imagine themselves being ordered by the police to do something.

To examine whether different people have different reasons for feeling they 'should' obey or disobey the police, we employ a combination of closed-ended and open-ended survey questions to probe the issue (Sturgis et al., 2020). People's own (i.e. open-ended) assessments of why they might or might not obey the police allow us to gauge the extent of normative and non-normative obedience. We analyse the qualitative data to form various motivational classifications.

\section{(2) Are motivations to comply with the law distinct from each other?}

We then use latent trait analysis (LTA) to investigate the correlations between different motives to obey or disobey officers, fear of the police, and normative alignment with the police. PJT distinguishes between normative and instrumental police-citizen relations (see left-hand side of Figure 2), where value-based motivations (that imply consensual modes of policing based on fairness and legitimacy) are conceptually and empirically distinct to deterrence-based motivations to comply (that imply coercive modes of policing on effectiveness and deterrence). ${ }^{1}$ But in São Paulo, are instrumental and normative police-citizen relations so distinct in people's minds? To foreshadow the findings, we find that a sizeable minority of people (around 20\%) who report a normatively grounded obligation to obey are also afraid of the police, and a sizeable minority of people (around 15\%) who report feeling normatively aligned with the police are also afraid of the police. If people can hold ambivalent feelings and attitudes toward the police, could instrumental and normative factors be placed on a continuum that ranges from instrumental at one end to normative at the other end, with some mixture of the two intermingling in the middle? Perhaps police-citizen relations are better represented not as two unipolar scales (the left-hand side of Figure 2) but as one bipolar scale that moves from instrumental to normative (the right-hand side of Figure 2)?

\section{INSERT FIGURE 2 ABOUT HERE}

\footnotetext{
${ }^{1}$ Instrumental relations are typically measured using items like 'I only obey police because I am afraid of them' (police-citizen relations), 'What is the likelihood that you be caught and punished if you bought something you think might be stolen?' (police/law-citizen relations), and 'Some laws are made to be broken' (law-citizen relations). To measure normative relations, researchers use items like 'I feel a moral duty to obey the police' (police-citizen relations), 'Your own feelings about what is right and wrong usually agree with the laws that enforced by the police and the courts' (police/law-citizen relations), and 'Obeying the law ultimately benefits everyone in the community' (law-citizen relations).
} 
(3) What are the predictors of legal compliance?

To foreshadow the LTA results, we find that a one latent trait model fits the data better than a two latent trait model (Appendix F), with the single latent trait akin to the coercive versus consensual relations approach depicted in Figure 2. In the final section of analysis we use the latent trait as a predictor of self-reported offending behavior, adjusting for people's belief about the morality of the acts. This allows us to test the idea in São Paulo that the more coercive the relationship between police and citizens, the more likely they are to report having committing crime; the more consensual the relationship, the less likely they are to report committing crime; and the more ambivalent the relationship, the more likely people are to fall in the middle part of the distribution of legal compliance.

\section{Data and methods}

Appendix F provides details about the measures and analytical strategy. A representative sample, faceto-face survey of adults in the city of São Paulo was conducted in June and July 2015. The final sample consisted of 1,804 respondents aged 16 and over living in 96 districts of the city, and was fairly representative of São Paulo as a whole in terms of key demographics. As just mentioned, we measured duty to obey using an open-ended question ("Do you think you have a duty to obey the police even when you believe they are wrong?" with binary "yes" or "no" response alternatives) and an openended follow-up question ("Why do you think you have/do not have a duty to obey the police even if you believe the police is wrong?"). Appendix E provides details about the thematic analysis on the open-ended question. After using LTA to assess the scaling properties of the different motives to obey or disobey the police, normative alignment, and fear of police, we test the extent to which measures of obligation to obey and the coercive to consensual continuum scale predict self-reported offending behavior, adjusting for geographical region, gender (self-identified male or female), age, income (with regards to the minimum wage, six categories), education (seven categories), self-reported racial identification (White, Black, Mixed White and Black, Asian-descendant, and Indigenous, see Appendix F for details of the classification system) and personal morality.

\section{Results}

(1) Are there different motives to feel (and not feel) obligated to obey the police? Assessing potential ambivalence in police-citizen relations

In total, $74 \%$ of respondents report feeling a duty to obey police (Table 1$)$. Just under half ( $46 \%$, or $34 \%$ of all respondents) indicate in the open-ended probe a sense of normatively-grounded obligation based on allowing the police to dictate appropriate behavior (Table 1 includes illustrative examples of the responses given to the open-ended question). This makes up what we call the "acceptance of rightful authority" group. The remainder of those who report feeling obligated to obey $(54 \%$, or $40 \%$ of all respondents) indicate that they would obey for instrumental reasons, e.g. to avoid the possibility of physical force from the officer. This makes up what we label the "coercive obligation" group. Turning to the $26 \%$ of respondents who report not feeling obligated to obey, just over two thirds $(69 \%$, or $18 \%$ of all respondents) say that they thought the police lack the moral right to expect voluntary compliance, a category labelled here "rejection of rightful authority". The remainder of those who say they did not feel a duty to obey the police ( $31 \%$, or $8 \%$ of all respondents) describe how they thought that officers might act in an immoral way and/or give illegitimate orders, so that they did not feel a duty because they see not complying as the right thing to do. This makes up what we call the "disobedient protest" group.

\section{INSERT TABLE 1 ABOUT HERE}

A significant minority of respondents report being afraid of the police (around 30\%). Table 2 shows that levels of fear are lower among those individuals who report a normative sense of obligation to obey $(20 \%)$ and a normatively-grounded duty to disobey the police (25\%), and higher among those who view the police as not having the rightful authority to give orders to citizens $(32 \%)$ and those who say they would comply because they fear the consequences of non-compliance (39\%). However, ambivalence is evident: (a) a relatively high number of those who express normative forms of obedience or disobedience also fear the police, and (b) a relatively high number of those who express an instrumental form of obligation to obey also do not fear the police. 
While the association between fear of the police and normative alignment with the police is a little stronger (see Table 3, e.g. of those who strongly agree with the statement 'The police act according to what I believe is right', $15 \%$ are afraid of the police, compared to $48 \%$ of those who strongly disagree), ambivalence was again present—some people who fear police also believe that officers act in normatively appropriate ways.

\section{INSERT TABLE 3 ABOUT HERE}

(2) Are instrumental and normative police-citizen relations two ends of a single continuum? These bivariate associations provide part of the motivation for the second step of the analysis: namely the LTA. Appendix F provides details, but to summarize we find that, while a two latent trait model that distinguishes between instrumental and normative factors fits the data, the one latent trait model (with instrumental factors at one end of the continuum, normative factors at the other, and ambivalence in the middle) fit the data even better. We therefore proceed with the one trait solution: parsimony has value and the data show considerable overlap in instrumental and normative sentiments, at least for some people. Appendix G gives a sense of what a given score on the coercive to consensual continuum corresponds to. In the middle of the coercive-consensual continuum are people who might not personally fear police, but think other people are afraid of police. They might feel a normative sense of obligation to disobey officers because they imagine that officers sometimes give immoral orders, and they might think that officers sometimes (but not always) act appropriately. At the consensual end of the continuum, people may not be particularly afraid of police (although they may tend to think other people are), they may feel a moral duty to obey officers, and they generally believe that officers always act appropriately. The coercive end of the continuum is characterized by fear of police (and think other people are too), not believing that officers act appropriately, and saying that they would disobey the order of officers because they reject their rightful authority.

\section{(3) Predictors of self-reported compliance with the law}

Finally, we turn to the question of whether the coercive to consensual continuum predict self-reported compliance. The results of the regression models can be found in Table $4 .^{2}$ Model 1 uses the original binary duty to obey variable, Model 2 uses the four content analysis categories, and Model 3 uses the coercive to consensual continuum. In the first model, only personal morality (people's beliefs about whether the various criminal acts are right or wrong) is significant; ceteris paribus, a unit increase in the score of personal morality is associated with decreasing the fitted odds of reporting higher levels of offending behavior by $46 \%$ (in the sense of the number of different types of crimes people report having committed). By contrast, the original duty to obey variable does not predict self-reported offending behavior, controlling for everything else in the model.

\section{INSERT TABLE 4 ABOUT HERE}

Model 2 finds a similar partial association for personal morality, and of the content analysis categories, the only significant predictor is acceptance of rightful authority (with coercive obligation as the reference category). All else being equal, belonging to the acceptance of rightful authority category (compared to falling in the coercive obligation category) is associated with a reduction of the fitted odds of higher levels of reported offending by $30 \%$. Neither belonging to the disobedient protest category, nor belonging to the rejection of rightful authority category, are significant predictors of offending behavior. Finally, Model 3 finds comparable statistical effects for personal morality, and the coercive to consensual continuum scale is also a significant predictor, with a unit increase in the latent trait is associated with a reduction of the fitted odds of higher levels of offending of $21 \%$.

A useful way of illustrating the results of Model 3 is to derive the fitted probabilities of the outcome, conditional on the changes in the coercive to consensual latent trait, while holding all other variables constant at their mean/reference category. Results are presented in Table 5. A standard deviation increase in the coercive to consensual latent trait corresponds, approximately, to a 5

\footnotetext{
${ }^{2}$ Alternative models were also tested with higher order effects of coercive power to consensual authority continuum (e.g., squared, cubic) and interactions with other variables (e.g., personal morality, gender). None of these were significant.
} 
percentage-point increase in the fitted probability of reporting having not committed any crime. In other words, the more normative respondents reported their relationship with the police was, the less likely they were to report committing crimes. Conversely, those whose relationship with police was based on fear and a lack of consent and appropriateness were more likely to report breaking the law.

\section{INSERT TABLE 5 ABOUT HERE}

\section{Discussion}

We started this paper with the idea that the social, political and legal context of São Paulo - a city with a long history of crime, police violence, relatively widespread fear of the police, and a popular sense in which force is often a central part of the exercise of power - may have implications for the sources of legitimacy, the nature of instrumental and normative police-citizen relations, and the link between legitimacy and legal compliance. Focusing on the predictors, nature and potential consequences of police legitimacy, we have addressed some of the ways in which the central tenets of PJT might need to adapt to the reality of policing in this city of the Global South. By reassessing the standard conception of legitimacy and its link to self-reported legal compliance, we also hope to contribute to ongoing debate about the meaning and measurement of legitimacy (Tyler, 2006a, 2006b; Bottoms \& Tankebe, 2012; Tyler \& Jackson, 2013; Hamm et al., 2017; Jackson \& Bradford, 2019; Trinkner, 2019; Oliveira \& Jackson, 2021).

Study one focused on the dimensions of police conduct that seem to legitimize the police in the eyes of citizens. We found that a fair amount of people in São Paulo tolerated-or at least were ambivalent towards - police use of excessive force against certain out-groups, and significant numbers believed that the police were ineffective against crime, treated different groups differently, and sometimes acted as if they were above the law. Yet, we also found even in a low trust, high fear, high police violence city like São Paulo - where certain forms of excessive use of force by the police are not firmly rejected by all, and where significant numbers believe the police to be ineffective, distributively unfair and acted as if they were above the law - a relational conception of procedural justice was key to the police being seen as legitimate by citizens.

Prior work has found that effectiveness and lawfulness judgements play a role in predicting empirical legitimacy in Pakistan, China and South Africa (Jackson et al. 2014; Bradford et al. 2014; Sun et al., 2018). This is consistent with PJT's prediction that, in contexts in which people generally have little inclination to be a member of the group that an authority represents, legitimacy may be judged more on instrumental factors like distributive justice and effectiveness than on the relational factor of procedural justice. It is also consistent with the idea that the police have to show a minimum ability to be control crime and corruption (Jackson et al. 2014; Bradford et al. 2014) and that authoritarianism may complicate the dynamics of police-citizen relations (Sun et al., 2018).

In São Paulo, by contrast, perceptions of procedural justice seem to be central to the moral recognition that legal institutions have a rightful claim of power. This suggests that the normative criteria upon which people rely to judge the appropriateness of the police exercise of legal power may mostly involve, as is the case in most Western democracies, fair process. If correct, this underlines the sense that (a) the Global South is not one big pool of 'other countries' in which police-citizen relations are homogeneously different from Anglo-American contexts, and (b) in some Global South contexts, similar social values as to the ones found in most Western democracies also have currency. It is for further research to address the extent to which people from different São Paulo neighborhoods identify with the superordinate group that the police represent is for future research to address (as well as unpicking how best to define and measure superordinate group identification, for general discussion see Radburn et al., 2016; Kyprianides et al., 2021).

Study two then found that the obligation to obey part of the legitimacy concept was more complex and more varied than has been typically found. While a fair number of respondents said that they felt a duty to obey police instructions, there were divergent reasons for this. Obedience was normative for some - it was premised in, and representative of, a relationship with police marked by rightful authority, i.e. what Tyler \& Trinkner (2018: 39) call the belief: ' $\ldots$ that it is appropriate and right for some external authority to make decisions about law and legal policy and that they ought to voluntarily follow those decisions, without concerns about reward and punishment'. But in other cases, obedience was prudential and/or essentially coerced, representing an instrumental motivation to comply based on fear of violence and intimidation (Tankebe, 2009; Bottoms \& Tankebe, 2012; Johnson et al., 2014). We also found that some people who said they did not feel a duty to obey officers went on to 
describe a defiance rooted in their belief that officers give immoral orders (see Murphy, 2021, for a discussion of resistant defiance toward authority).

Crucially, ambivalence was a key characteristic of police-citizen relations among study two participants, with instrumental and normative factors seeming to 'mix' on occasion, e.g. some people both feared the police and believed that they acted in normative appropriate ways. Police-citizen authority relations in São Paulo could, we argued, be usefully conceived as existing on a coercive to consensual continuum, moving from an instrumental from one end, to ambivalence in the middle, to a normative relationship at the other. The instrumental end was based on fear of police, the belief that officers act in normatively inappropriate ways, and either an instrumental obligation to obey officers or a normative obligation to disobey based on the belief that police lack rightful authority. People who fell in the middle of the continuum exhibited an ambivalent mix of both instrumental and normative connections to the police. They might have thought that the police 'sometimes' or 'almost always' act appropriately while also feeling an instrumental obligation to obey the police and thinking that people often fear the police. They were also more likely to feel an obligation to disobey the police out of a sense of civic protest, thinking for example that the police might issue an immoral order. The normative end was based on a lack of fear of police, the belief that officers act in normatively appropriate ways, and their belief that they have rightful authority.

\section{Limitations}

In the closing section of the paper, we consider the broader theoretical and policy implications of all these findings. But before we get there, we should acknowledge some limitations of our empirical work. First, the data are observational. Second, we rely on self-reports. Third, some of the measures could be improved. For example, distributive justice was measured using a single item that asks whether the police treated rich, white people better than poor, black/brown people. We recommend future studies measure the broad range of 'goods' and 'bads' of policing, assessing people's views on whether the police provide the same level of security, the same quality of service, enforce the law consistently, deploy their resources in an equitable manner, and ensure that everyone has equal access to the services they provide.

Fourth, respondents in study two were asked whether they felt an obligation to obey the police, and an open-ended probe was then used to try to understand what they meant when they said 'yes' or 'no.' People who are more articulate and/or more educated may tend to give more detailed and introspective responses to open-ended survey questions, and therefore potentially better quality data (Groves et al., 2011). In the current context, it could be that more educated people had greater insight into their nature of their sense of (or lack of) obligation and were more articulate and detailed in their answers. Normative reasons may be less intuitive than instrumental reasons (as one of the anonymous referees suggests). So more educated people may be more likely to report normative motivations, simply as a function of the methodology. It is for future work to explore this issue.

Fifth, people who are inclined to commit crime (or have recently committed a crime or two) may be more likely to think about the police in instrumental terms because they may be more attuned to police surveillance, the chance of getting arrested, being seen as someone to regulate rather than protect etc. They may therefore report an instrumental motivation to obey or disobey the police. Future studies should try to unpick the temporal, causal ordering here. Sixth, we did not address the full range of instrumental and normative factors when predicting legal compliance, most notably deterrence perceptions. Future work could address likelihood, celerity and severity. Seventh, the two surveys did not measure identification with the superordinate group that the police are assumed to represent (cf. Bradford et al., 2014a) or relational identification (Kyprianides et al., 2021b). While it does seem that this social group was meaningful and important to the legitimation of the police given the strong role that procedural justice played, this is something that needs to be tested more directly (and for recent work into the potentially reciprocal nature of justice and inclusion, see Martin \& Zyphur, 2021). Finally, there was no space in the current paper to include multi-group analysis and demographic differences in police-citizen relations.

\section{Conclusion}

We started this paper with the observation that Brazil's largest city represents a different context to the settings that PJT have traditionally been tested. The metropolitan region of São Paulo has 18 million residents and the city itself is considered one of the most unequal in the world (Nery et al., 2019). Amid a sea of skyscrapers, the landscape can swiftly change from astonishing developments for the well-off 
to favelas, where a large proportion of the poor population dwells. In most neighborhoods, crime rates are relatively high, and scholars have interpreted the persistence of social violence in the country as evidence of a weak rule of law (Adorno, 2013). Cases of police violence perpetrated by officers of the São Paulo Military Police are common: in 2019, 13\% of all 45,000 victims of murder were killed by security forces. The city is also a leading example of criminal governance, as the PCC (Primeiro Comando da Capital), a powerful prison gang, governs extensively, ruling large urban populations across enormous swaths of territory (Lessing and Willis, 2019).

We are not the first to say that the PJT literature could benefit from more examination of policecitizen relations in the Global South (see, for instance, Tankebe, 2009; Jackson et al., 2014a, 2014b; Cheng, 2015; Akinlabi, 2017; Sun et al., 2017). In addition to finding that procedural justice is key, we found significant ambivalence in police-citizen authority relations, and to some degree the consensual/coercive continuum that best represented people's complex attitudes maps onto some distinctive styles of policing in São Paulo. Representing heavily militarized police forces, armed officers routinely stop and question members of the public at gunpoint, especially in disadvantaged communities (Oliveira, 2021). People are generally exposed to both police and neighborhood violence, and often hear stories of summary killings of gang members (Lessing and Willis, 2019).

While it is true that some in our study were located at the consensual end of the spectrum, while other people were located at the coercive end, there was extensive ambivalence among others suggesting a complex scenario where the threat of violence is salient in the exercise of power by authority figures. Strikingly however, even in such a context, the continuum predicted legal compliance. We do only have correlational data, but our findings are suggestive of the idea that procedurally just policing tactics encourage legitimacy, and normative obedience and lack of fear of police encourage people to voluntarily comply with the law. It is for future studies to untangle the issue of causality here, as well as address the predictors of fear of policing, instrumental obedience, normative non-obedience, and other factors.

Overall, PJT seems to apply even in São Paulo, albeit the framework needs to somewhat adapt to match the context. Procedural justice seems key, and when complicating factors are acknowledged and incorporated into the analytical strategy, legitimacy is related to legal compliance. As in the US, UK and other similar contexts, it may be that by generating normative self-regulation using proceduraljustice based approaches, legal authorities can reduce the need for more aggressive modes of social control, managing social order through nurturing and sustaining widespread feelings of obligation and responsibility toward law and legal authority (Tyler, 2006a, 2006b).

It is often assumed that even if people do not comply with the law for legitimacy-based reasons, then instrumental motivations may still be in play, at least in some times and places. On this account, if all else fails, aggressive policing that demonstrates the risks of non-compliance can hold the line. But our results suggest that when people obey police through fear, this may not only fail to increase legal compliance but actually diminish it. Policing styles oriented toward attempts to increase prudential compliance, at least as far as this is generated by fear of the police, may therefore be actively counterproductive, and indeed criminogenic.

Bittner argues that police are "a mechanism for the distribution of non-negotiably coercive force" (1990:131). In most countries around the world, non-compliance with police instructions may in certain circumstances risk violence. If the policed do not comply through the mechanism of legitimacy, they may be coerced, ultimately by force. Put another way, compliance with police instructions is likely to be forthcoming in the large majority of cases, whether it stems from normative or instrumental concerns, and this brute fact should be taken into account in our models of public obedience toward police. What is at stake in PJT is the reason for obedience; the claim being that normative compliance (willing consent) is both ethically more desirable and a more sustainable model for police authority and the exercise of power. In as much as they suggest that coerced compliance may be actively criminogenic, our results here are at least consistent with this latter claim. 


\section{References}

Adorno, Serge. 2013. "Democracy in progress in contemporary Brazil" International Journal of Criminology and Sociology, 2, 409-425.

Akinlabi OM. 2017. "Young people, procedural justice and police legitimacy in Nigeria." Polic. Soc. 27(4):419-38

Akinlabi, O. M., \& Murphy, K. (2018). "Dull compulsion or perceived legitimacy?" Police Practice and Research, 19 (2), 186-201.

Applbaum, Arthur Isak. 2019. Legitimacy: The Right to Rule in a Wanton World. Cambridge, MA: Harvard University

Batitucci, Eduardo Cerqueira. 2010. "A evolução institucional da polícia no século xix:" R. Brasileira de Segurança Pública, 4: 30-46.

Bittner, Egon. 1990. Aspects of Police Work. Boston: Northeastern University Press.

Bolger, Colin P. and Glenn D. Walters. 2019. "The relationship between police procedural justice, police legitimacy, and people's willingness to cooperate with law enforcement: A meta-analysis." Journal. of Criminal Justice, 60 (1): 93-9.

Bottoms, Anthony and Justice Tankebe. 2012. "Beyond procedural justice: A dialogic approach to legitimacy in criminal justice.” J. of Criminal Law \& Criminology, 102 (1): 119-70.

Bradford B. and Jackson, J. 'Legitimacy, Relational Norms and Reciprocity', in Hollander-Blumoff, R. (ed.) Research Handbook in Law and Psychology. Elgar Press.

Bradford, B., Milani, J. and Jackson, J. 2017. "Identity, Legitimacy and "Making Sense" of Police Use of Force', Policing: An International Journal of Police Strategies and Management, 40 (3): 614627.

Bradford, Ben, Aziz Huq, Jonathan Jackson and Ben Roberts. 2014b. "What price fairness when security is at stake?" Regulation \& Governance, 8 (2): 246-68.

Bradford, Ben, Kristina Murphy and Jonathan Jackson. 2014a. "Officers as mirrors". British Journal of Criminology, 54 (4): 527-50.

Bradford, Ben. 2014. "Policing and social identity". Policing \& Society 24 (1): 22-43.

Briceño-León, Roberto, Leandro Piquet Carneiro, and José Miguel Cruz. 1999. "O Apoio dos Cidadãos à Ação Extrajudicial da Polícia no Brasil, em El Salvador e na Venezuela." Pandolfi, Dulce Chaves et alii (orgs.), Cidadania, Justiça e Violência, Rio de Janeiro, Fundação Getúlio Vargas.

Buchanan, Allen E. Justice, Legitimacy, and Self-determination: Moral Foundations for International Law. Oxford University, 2007.

Caldeira, Teresa P. R. 2002. "The Paradox of Police Violence in Democratic Brazil." Ethnography, 3 (3): 235-63.

Caldeira, Teresa P. R. and James Holston. 1999. "Democracy and Violence in Brazil." Comparative Studies in Society and History, 41 (4): 691-729.

Cardia, Nancy, et al.. 2014. "PercepPções Sobre a Justiça entre Moradores da Cidade de São Paulo: 2001-2013." Revista USP, 101: 159-72.

Cheng KK-y. 2015. "Prosecutorial procedural justice and public legitimacy in Hong Kong". $B r . J$. Criminology 57(1):94-111

de Oliveira Junior, Almir and Rafael Augusto da Costa Alencar. 2015. "A Predisposição para Chamar a Polícia." Rev. Brasileira de Segurança Pública, 9 (1): 158-70.

Dias, Camila Caldeira Nunes. 2011. "Da pulverização ao monopólio da violência" $\mathrm{PhD}$ diss., Universidade de São Paulo.

Filgueiras, Fernando. 2013. "Perceptions on Justice, the Judiciary and Democracy." Brazilian Political Science Review, . 7 (2): 62-87.

Forum Brasileiro de Segurança Pública. 2017. "11º Anuário Brasileiro de Segurança Pública." São Paulo: Fórum Brasileiro de Seguranca Publica.

Garmany, Jeff. 2014. "Space for the State? Police, Violence, and Urban Poverty in Brazil." Annals of the Association of American Geographers. 104 (6): 1239-255.

Gerber, M. and Jackson, J. 2017. "Justifying Violence”. Psychology, Crime and Law, 23 (1): 79-95.

Gerber, M. M., et al.. 2018. "On the Justification of Intergroup Violence". Psychology of Violence, 8 (3): 379-389.

Glöckner, Andreas, et al. 2019. "Integrating Theories of Law Obedience". Judgement and Decision Making 14 (3): 318-34.

Goldstein, Donna M. 2003. Laughter Out of Place: Race, Class, Violence, and Sexuality in a Rio Shantytown. Berkeley: University of California Press. 
Groves, R. M., Fowler Jr, F. J., Couper, M. P., Lepkowski, J. M., Singer, E., \& Tourangeau, R. (2011). Survey Methodology. John Wiley \& Sons.

Guimarães, Juliany Gonçalves, Ana Raquel Rosas Torres and Margareth RGV De Faria. 2005 "Democracia e Violência Policial: O Caso da Polícia Militar." Psicologia em Estudo, 10 (2): 26371.

Hough, Mike. 2020. Good Policing: Trust, Legitimacy and Authority. Bristol: Policy Press.

Huggins, Martha K. 2000. "Legacies of Authoritarianism: Brazilian Torturers' and Murderers" Reformulation of Memory." Latin American Perspectives, 27 (2): 57-78.

Huq, Aziz Z, Jonathan Jackson and Rick J. Trinkner. 2017. "Legitimating Practices: Revisiting the Predicates of Police Legitimacy." British Journal. of Criminology, 57 (5): 1101-22. identity, and cooperative behavior." Personality and Social Psychology Review, 7, 349-361.

Jackson, J., Huq, A., Bradford, B. and Tyler, T. R. 2013a. "Monopolizing Force?". Psychology, Public Policy and Law, 19 (4): 479-497.

Jackson, Jonathan and Ben Bradford. 2019. "Blurring the Distinction between Empirical and Normative Legitimacy?” Asian Journal. of Criminology, 14 (4): 265-89.

Jackson, Jonathan and Jacinta Gau. (2016). "Carving up Concepts? Differentiating between Trust and Legitimacy in Public Attitudes towards Legal Authority", in Shockley, E., Neal, T. M. S., PytlikZillig, L. and Bornstein, B. (eds.) Interdisciplinary Perspectives on Trust: Towards Theoretical and Methodological Integration. New York: Springer, pp. 49-69.

Jackson, Jonathan, Ben Bradford, Betsy Stanko and Katrin Hohl. 2013b. Just Authority? Trust in the Police in England and Wales. Oxon: Routledge.

Jackson, Jonathan, et al.. 2012. "Why do People Comply with the Law?" British Journal. of Criminology, 52 (6): 1051-71

Jackson, Jonathan, et al.. 2014. "Corruption and Police Legitimacy in Lahore, Pakistan." British Journal of Criminology, 54 (6): 1067-88.

Jackson, Jonathan. 2018. "Norms, Normativity and the Legitimacy of Legal Authorities: International Perspectives.", Annual Review of Law and Social Science, 14, 145-165.

Johnson, Devon, Edward R. Maguire and Joseph B. Kuhns. 2014. "Public perceptions of the legitimacy of the law and legal authorities". Law \& Society Review, . 48 (4): 947-978.

Jonathan-Zamir, Tal and David Weisburd. 2013. "The Effects of Security Threats on Antecedents of Police Legitimacy." J. of Research in Crime and Delinquency 50 (1): 3-32.

Kirk, David S. and Andrew V Papachristos. 2011. "Cultural mechanisms and the persistence of neighborhood violence." American Journal of Sociology, 116 (4): 1190-1233.

Kyprianides, Arabella, et al., 2021a. "Need to Survive: Legal Compliance among a Homeless Street Population". Law \& Human Behavior.

Kyprianides, Arabella, et al.. 2021b. "Identity, Legitimacy and Cooperation with the Police: Comparing General-Population and Street-Population Samples in London.” Psychology, Public Policy \& Law.

Lang, Kyle M. and Wei Wu. 2017. "A Comparison of Methods for Creating Multiple Imputations of Nominal Variables.” Multivariate Behavioral Research 52 (3): 290-304.

Lessing, B. and G. D. Willis. 2019. "Legitimacy in criminal governance: Managing a drug empire from behind bars." American Political Science Review 113 (2): 584-606.

Lima, Renato S., Sinhoretto, J., and Bueno, Samira. 2015. "A gestão da vida e da segurança pública no Brasil." Sociedade e Estado, 30 (1), 123-144.

Lind, E. Allan and Tom R. Tyler. 1988. The Social Psychology of Procedural Justice. New York: Plenum.

Martin, Chris C., and Michael J. Zyphur. 2021. "Justice and Inclusion Mutually Cause Each Other." Social Psychological and Personality Science. August 2021.

Mazerolle, Lorraine, Emma Antrobus, Sarah Bennett and Tom R. Tyler. 2013. "Shaping Citizen Perceptions of Police Legitimacy" Criminology, 51 (1): 33-63.

McLean, K. (2020), 'Revisiting the Role of Distributive Justice in Tyler's Legitimacy Theory', Journal of Experimental Criminology, 16, 335-46.

Mentovich, Avital et al.. 2018. "Policing Alienated Minorities in Divided Cities." Regulation \& Governance, 14 (3): 531-550.

Mitchell, Michael J. and Charles H. Wood. 1999. "Ironies of Citizenship: Skin Color, Police Brutality, and the Challenge to Democracy in Brazil." Social Forces, 77 (3): 1001-1020. 
Murphy, K. 2021. "Scrutiny, legal socialization, and defiance". Journal of Social Issues.

Nagin, D. S., \& Telep, C. W. 2020. "Procedural justice and legal compliance: A revisionist perspective." Criminology \& Public Policy, 19(3), 761-786.

Nagin, Daniel S., \& Cody W. Telep. 2017. "Procedural Justice and Legal Compliance." Annual Review of Law and Social Science, 13, 5-28.

Nery, Marcelo B., Altay A. L. Souza, \& Sergio Adorno. 2019. "Os padrões urbano-demográficos da capital paulista." Estudos Avançados, 33 (97): 5-36.

Oliveira Júnior, Almir. 2011. "Dá para Confiar nas Polícias?" Rev. Brasileira de Segurança Pública, 9 (2): 6-22.

Oliveira, Thiago R. (2021). "Violence and Coercive Policing: Dynamics and Consequences of the Overpolicing-underpolicing Paradox in Brazil's Largest City." SocArXiv: https://doi.org/10.31235/osf.io/89jkv.

Oliveira, Thiago R., and Jonathan Jackson. 2021. "Legitimacy, trust and legal cynicism: A review of concepts." SocArXiv, Oct 132021.

Oliveira, Thiago R., André Rodrigues de Oliveira and Sergio Adorno. 2019. "Legitimidade da Polícia: Um Modelo de Mensuração." Rev. Brasileira de Ciências Sociais, 34 (100): 1-25.

Oliveira, Thiago R., André Zanetic and Ariadne Lima Natal. 2020. "Preditores e Impactos da Legitimidade Policial." Dados - Revista de Ciências Sociais, 63 (1).

Oliveira, Thiago R., et al. 2020. "Are trustworthiness and legitimacy "hard to win, easy to lose"” Journal of Quantitative Criminologdoi.org/10.1007/s10940-020-09478-2.

Oliveira, Thiago R., et al.. 2021. "Socialization through Violence: Exposure to Neighborhood and Police Violence and the Development of Legal Legitimacy Among Adolescents in São Paulo." Working paper.

Osgood, D. W., McMorris, B. J., \& Potenza, M. T. 2002. "Analyzing multiple-item measures of crime and deviance I" Journal of Quantitative Criminology, 18: 267-296.

Paes-Machado, Eduardo and Ceci Vilar Noronha. 2002. "Policing the Brazilian Poor", International Criminal Justice Review, 12 (1): 53-76.

Papachristos, Andrew, Tracey Meares and Jeffrey Fagan. 2012. "Why do Criminals Obey the Law?" Journal of Criminal Law \& Criminology, 102: 397-440.

Pereira, Anthony W. and Mark Ungar. 2004 "The Persistance of the Mano Duro: Authoritarian Legacies and Policing in Brazil and the Southern Cone," in Authoritarian Legacies and Democracy in Latin American and Southern Europe, edited by Katherine Hite and Paola Cesarini. Notre Dame: Notre Dame University Press.

Peres, Maria Fernanda Tourinho, et al.. 2008. "Homicídios, Desenvolvimento Socioeconômico e Violência Policial no Município de São Paulo, Brasil." Revista Panamericana de Salud Publica, 23: 268-76.

Pinheiro, Paulo Sérgio. 1991. “Autoritarismo e Transição.” Rev.evista Universidade de São Paulo, 9: 45-56.

Posch, Krisztián, Jonathan Jackson, Ben Bradford and Sarah MacQueen. 2020. “"Truly Free Consent'? Clarifying the Nature of Police Legitimacy using Causal Mediation Analysis", Journal of Experimental Criminology

Radburn, M., Stott, C., Bradford, B., \& Robinson, M. (2018). When is policing fair? Groups, identity and judgements of the procedural justice of coercive crowd policing. Policing and Society, 28(6), 647-664.

Ruotti, Caren. 2016. "Pretensão de Legitimidade do PCC: Justificação e Reconhecimento de suas Práticas nas Periferias da Cidade de São Paulo.” PhD. Dissertation. Universidade de São Paulo.

Sampson, Robert J. and Dawn J Bartusch. 1998. "Legal cynicism and (subcultural?) tolerance of deviance." Law and Society Review, 32 (4): 777-804.

Schwarcz, Lilia Moritz and Heloisa Murgel Starling. 2015. Brasil: Uma Biografia. São Paulo, Brazil: Editora Schwarcz.

Silva, Geélison F. and Cláudio Beato. 2013. "Confiança na Polícia em Minas Gerais.” Opinião Pública, 19 (1): 118-53.

Sturgis, Patrick, Ian Brunton-Smith, and Jonathan Jackson. 2020. "Regression-based Response Probing for Assessing the Validity of Survey Questions", in Beatty, P., Willis, G. and Padilla, J-L (eds.) Advances in Questionnaire Design, Development, Evaluation and Testing. Wiley, pp. 571-591.

Sun IY, et al.. 2017. "Procedural justice, legitimacy, and public cooperation with police?" J. Res. Crime Delinq. 54(4):454-78 
Sun, Ivan Y., et al.. 2018. "Police Legitimacy and Citizen Cooperation in China." Asian Journal of Criminology, 13 (4): 275-291.

Sunshine, Jason and Tom R. Tyler. 2003. "The Roles of Procedural Justice and Legitimacy in Shaping Public Support for Policing." Law \& Society Review., 37 (3): 513-48.

Sweeten, Gary. 2012. "Scaling Criminal Offending." Journal of Quantitative Criminology, 28 (3): 533557.

Tankebe, Justice. 2009. "Public Cooperation with the Police in Ghana" Criminology, 47 (4): 1265-93.

Trinkner, Rick, and Tom R. Tyler. 2016. "Legal Socialization: Coercion versus Consent in an Era of Mistrust." Annual Review of Law \& Social Science, 12: 417-39.

Trinkner, Rick, et al.. 2020. "Legal Socialization in Brazil." International Journal. of Comparative and Applied Criminal Justice, .44 (1-2): 7-27.

Trinkner, Rick, Jonathan Jackson and Tom R. Tyler. 2018. "Bounded Authority: Expanding "Appropriate" Police Behavior Beyond Procedural Justice." Law \& Human Behavior, 42 (3): 280-93.

Trinkner, Rick. 2019. "Clarifying the Contours of the Police Legitimacy Measurement Debate: A Response to Cao and Graham." Asian Journal. of Criminology 14 (4): 309-35.

Tyler, T. R., \& Blader, S. L. 2000. Cooperation in groups: Procedural justice, social identity, and behavioral engagement. Philadelphia, PA: Psychology Press.

Tyler, T. R., \& Blader, S. L. 2003. "The group engagement model",

Tyler, T. R., \& Folger, R. 1980. "Distributional and procedural aspects of satisfaction with citizenpolice encounters." Basic and Applied Social Psychology, 1 (4): 281-292.

Tyler, T. R., \& Lind, E. A. (1992). "A relational model of authority in groups." Advances in Experimental Social Psychology, 25, 115-191.

Tyler, Tom R. 2006a. Why People Obey the Law. New Haven, CT: Yale University Press.

Tyler, Tom R. 2006b. "Psychological Perspectives on Legitimacy and Legitimation." Annual Review. of Psychology 57: 375-400.

Tyler, Tom R. and Jonathan Jackson. 2013. "Future Challenges in the Study of Legitimacy and Criminal Justice" in Legitimacy and Criminal Justice: An International Exploration, edited by Justice Tankebe and Alison Liebling. Oxford: Oxford University Press, pp. 83-104.

Tyler, Tom R. and Jonathan Jackson. 2014. "Popular Legitimacy and the Exercise of Legal Authority." Psychology, Public Policy and Law, 20 (1): 78-95.

Tyler, Tom R. and Rick Trinkner 2017. Why Children Follow Rules: Legal Socialization and the Development of Legitimacy. New York: Oxford University Press.

Tyler, Tom R. and Yuen Huo. 2002 Trust in the Law: Encouraging Public Cooperation with the Police and Courts. New York: Russell Sage Foundation.

Tyler, Tom, Jonathan Jackson and Avital Mentovich. 2015. "On the Consequences of Being a Target of Suspicion" Journal of Empirical Legal Studies, 12 (4): 602-636.

Tyler, Tom. 2017. "Procedural justice and policing: A rush to judgment?" Annual Review of Law and Social Science, 13: 29-53.

Walters, Glenn D., and P. Colin Bolger. 2019. "Procedural Justice Perceptions, Legitimacy Beliefs, and Compliance with the Law: A Meta-analysis." Journal of Experimental Criminology 15 (3): 34172 .

Willis, Graham Denyer. 2015. The Killing Consensus: Police, Organized Crime, and the Regulation of Life and Death in Urban Brazil. Oakland. University of California Press.

Zanetic, André, et al.. 2016. "Legitimidade da Polícia: Segurança Pública para além da Dissuasão." Civitas: Rev. de Ciências Sociais 16 (4): 148-73.

Zanetic, André. 2017. "Ação institucional, confiança na polícia e legitimidade em São Paulo.” Revista Brasileira de Ciências Sociais 32 (95): 1-19. 
Table 1: Answers to the closed-ended duty to obey question and the four categories derived by the content analysis of the open-ended follow-up question

\begin{tabular}{|c|c|c|c|}
\hline \multirow[b]{2}{*}{ Motivation } & \multicolumn{3}{|c|}{ Do you think you have a duty to obey the police even when you believe they are wrong? Yes or no? } \\
\hline & $\begin{array}{c}\text { Yes } \\
(74 \%)\end{array}$ & & $\begin{array}{l}\text { No } \\
26 \%)\end{array}$ \\
\hline $\begin{array}{c}\text { Normative } \\
\text { reasoning }\end{array}$ & $\begin{array}{l}\text { Acceptance of rightful authority } \\
\qquad(34 \%) \\
\text { "It is the citizen's duty to act in } \\
\text { accordance with the law"; } \\
\text { "The police officer represents the } \\
\text { law and must be respected"; } \\
\text { "We must obey the police, whether } \\
\text { it's right or wrong" }\end{array}$ & $\begin{array}{l}\text { Disobedient protest (8\%) } \\
\text { "They are wrong and if I obey I } \\
\text { will be going against my beliefs"; } \\
\text { "Laws are for everyone and I can } \\
\text { call internal affairs"; } \\
\text { "I must make the officer } \\
\text { understand my point of view", }\end{array}$ & $\begin{array}{l}\text { Rejection of rightful authority (18\%) } \\
\text { "Because you cannot trust them"; } \\
\text { "Because they wear uniforms and } \\
\text { have the prerogative to say what } \\
\text { the law is, and then engage in } \\
\text { abuse of authority"; } \\
\text { "Because they are corrupt and are } \\
\text { worse than many outlaws" }\end{array}$ \\
\hline $\begin{array}{l}\text { Instrumental } \\
\text { reasoning }\end{array}$ & $\begin{array}{l}\text { Coercive obligation } \\
\qquad(40 \%)\end{array}$ & & \\
\hline
\end{tabular}


Table 2: Fear of the police and forms of obligation to obey/not to obey the police

\begin{tabular}{|l|c|c|c|}
\hline & Are you afraid of the police? Yes or no? & \\
\hline Motivation & Yes & No & Total \\
\hline $\begin{array}{l}\text { Acceptance of rightful authority } \\
\text { (normative) }\end{array}$ & $99(20 \%)$ & $385(80 \%)$ & $484(100 \%)$ \\
\hline Disobedient protest (normative) & $23(25 \%)$ & $68(75 \%)$ & $91(100 \%)$ \\
\hline Coercive obligation (instrumental) & $209(39 \%)$ & $321(61 \%)$ & $530(100 \%)$ \\
\hline Rejection of rightful authority (normative) & $83(32 \%)$ & $178(68 \%)$ & $261(100 \%)$ \\
\hline Total & $414(30 \%)$ & $952(70 \%)$ & $1366(100 \%)$ \\
\hline
\end{tabular}


Table 3: Fear of the police and normative alignment with the police

\begin{tabular}{|l|c|c|c|}
\hline & \multicolumn{2}{|c|}{ Are you afraid of the police? Yes or no? } & \\
\hline $\begin{array}{l}\text { Normative alignment with } \\
\text { the police }\end{array}$ & Yes & No & Total \\
\hline Never act appropriately & $140(48 \%)$ & $150(52 \%)$ & $290(100 \%)$ \\
\hline Rarely act appropriately & $103(45 \%)$ & $126(55 \%)$ & $229(100 \%)$ \\
\hline Sometimes act appropriately & $101(28 \%)$ & $259(72 \%)$ & $360(100 \%)$ \\
\hline $\begin{array}{l}\text { Almost always act } \\
\text { appropriately }\end{array}$ & $60(23 \%)$ & $206(77 \%)$ & $266(100 \%)$ \\
\hline Always act appropriately & $50(15 \%)$ & $285(85 \%)$ & $335(100 \%)$ \\
\hline Total & $454(31 \%)$ & $1026(69 \%)$ & $1480(100 \%)$ \\
\hline
\end{tabular}


Table 4: Ordinal regression analysis with odds ratios, multiple imputation and clustered robust standard errors for the sampling regions in squared brackets

\begin{tabular}{|c|c|c|c|}
\hline & Model1 & Model2 & Model3 \\
\hline Duty to obey & $\begin{array}{c}1.107 \\
{[0.118]}\end{array}$ & & \\
\hline \multicolumn{4}{|l|}{ Content analysis categories } \\
\hline Acceptance of rightful authority & & $\begin{array}{c}0.700 * * * \\
{[0.062]}\end{array}$ & \\
\hline Disobedient protest & & $\begin{array}{c}0.702 \\
{[0.153]}\end{array}$ & \\
\hline Rejection of rightful authority & & $\begin{array}{c}0.809 \\
{[0.141]}\end{array}$ & \\
\hline Coercive/consensual continuum & & & $\begin{array}{c}0.795^{* * *} * \\
{[0.036]}\end{array}$ \\
\hline Personal morality & $\begin{array}{c}0.540^{* * *} \\
{[0.025]}\end{array}$ & $\begin{array}{c}0.544 * * * \\
{[0.026]}\end{array}$ & $\begin{array}{c}0.546^{* * *} \\
{[0.025]}\end{array}$ \\
\hline Female & $\begin{array}{c}0.708^{* *} \\
{[0.074]}\end{array}$ & $\begin{array}{l}0.708 * * \\
{[0.076]}\end{array}$ & $\begin{array}{l}0.699 * * \\
{[0.072]}\end{array}$ \\
\hline Age & $\begin{array}{c}0.992^{*} \\
{[0.004]}\end{array}$ & $\begin{array}{c}0.993 \\
{[0.004]}\end{array}$ & $\begin{array}{c}0.995 \\
{[0.004]}\end{array}$ \\
\hline \multicolumn{4}{|l|}{ Income } \\
\hline $1-2$ times the minimum wage & $\begin{array}{c}1.043 \\
{[0.192]}\end{array}$ & $\begin{array}{c}1.065 \\
{[0.196]}\end{array}$ & $\begin{array}{c}1.063 \\
{[0.192]} \\
\end{array}$ \\
\hline $2-5$ times the minimum wage & $\begin{array}{l}1.455^{* *} \\
{[0.192]}\end{array}$ & $\begin{array}{l}1.490^{* *} \\
{[0.211]}\end{array}$ & $\begin{array}{l}1.497^{* *} \\
{[0.196]}\end{array}$ \\
\hline $5-10$ times the minimum wage & $\begin{array}{l}1.565^{* *} \\
{[0.262]}\end{array}$ & $\begin{array}{l}1.585^{* *} \\
{[0.267]}\end{array}$ & $\begin{array}{l}1.546^{* *} \\
{[0.243]}\end{array}$ \\
\hline $10-20$ times the minimum wage & $\begin{array}{c}1.539 \\
{[0.440]}\end{array}$ & $\begin{array}{c}1.544 \\
{[0.431]}\end{array}$ & $\begin{array}{c}1.575 \\
{[0.444]}\end{array}$ \\
\hline $20+$ times the minimum wage & $\begin{array}{c}1.001 \\
{[0.399]}\end{array}$ & $\begin{array}{c}0.988 \\
{[0.396]}\end{array}$ & $\begin{array}{c}1.039 \\
{[0.403]}\end{array}$ \\
\hline \multicolumn{4}{|l|}{ Education } \\
\hline Literate, no schooling & $\begin{array}{c}0.308^{* * * *} \\
{[0.093]}\end{array}$ & $\begin{array}{c}0.320 * * * \\
{[0.096]}\end{array}$ & $\begin{array}{c}0.289^{* * *} \\
{[0.087]}\end{array}$ \\
\hline Incomplete primary school & $\begin{array}{c}0.610 \\
{[0.181]}\end{array}$ & $\begin{array}{c}0.623 \\
{[0.183]}\end{array}$ & $\begin{array}{c}0.570^{*} \\
{[0.157]}\end{array}$ \\
\hline Complete primary school & $\begin{array}{c}0.608 \\
{[0.241]} \\
\end{array}$ & $\begin{array}{c}0.633 \\
{[0.183]} \\
\end{array}$ & $\begin{array}{c}0.569 \\
{[0.218]}\end{array}$ \\
\hline Incomplete elementary school & $\begin{array}{c}0.873 \\
{[0.285]}\end{array}$ & $\begin{array}{c}0.633 \\
{[0.249]} \\
\end{array}$ & $\begin{array}{c}0.828 \\
{[0.260]}\end{array}$ \\
\hline Complete elementary school & $\begin{array}{c}0.916 \\
{[0.308]}\end{array}$ & $\begin{array}{c}0.908 \\
{[0.282]}\end{array}$ & $\begin{array}{c}0.852 \\
{[0.288]}\end{array}$ \\
\hline Incomplete high school & $\begin{array}{c}1.018 \\
{[0.341]}\end{array}$ & $\begin{array}{c}0.940 \\
{[0.312]}\end{array}$ & $\begin{array}{c}0.980 \\
{[0.300]}\end{array}$ \\
\hline Complete high school & $\begin{array}{c}1.192 \\
{[0.347]}\end{array}$ & $\begin{array}{c}1.048 \\
{[0.352]}\end{array}$ & $\begin{array}{c}1.150 \\
{[0.322]} \\
\end{array}$ \\
\hline Incomplete college & $\begin{array}{c}1.268 \\
{[0.484]}\end{array}$ & $\begin{array}{c}1.237 \\
{[0.358]}\end{array}$ & $\begin{array}{c}1.259 \\
{[0.453]}\end{array}$ \\
\hline Complete college & $\begin{array}{c}0.928 \\
{[0.381]}\end{array}$ & $\begin{array}{c}1.310 \\
{[0.499]}\end{array}$ & $\begin{array}{c}0.898 \\
{[0.350]}\end{array}$ \\
\hline \multicolumn{4}{|l|}{ Ethnicity } \\
\hline Black (Afro-descendant) & $\begin{array}{c}1.069 \\
{[0.155]}\end{array}$ & $\begin{array}{c}1.061 \\
{[0.157]}\end{array}$ & $\begin{array}{c}1.020 \\
{[0.151]}\end{array}$ \\
\hline Mixed (White-Black) & $\begin{array}{c}0.989 \\
{[0.139]}\end{array}$ & $\begin{array}{c}0.994 \\
{[0.138]}\end{array}$ & $\begin{array}{c}0.971 \\
{[0.136]} \\
\end{array}$ \\
\hline Asian-descendant & $\begin{array}{c}0.739 \\
{[0.202]}\end{array}$ & $\begin{array}{c}0.697 \\
{[0.191]}\end{array}$ & $\begin{array}{c}0.758 \\
{[0.203]}\end{array}$ \\
\hline Native Brazilian & $\begin{array}{c}0.794 \\
{[0.280]}\end{array}$ & $\begin{array}{c}0.819 \\
{[0.271]}\end{array}$ & $\begin{array}{c}0.800 \\
{[0.282]}\end{array}$ \\
\hline \multicolumn{4}{|l|}{ Intercepts } \\
\hline Cutoff1 & 0.015 & 0.013 & 0.016 \\
\hline Cutoff2 & 0.063 & 0.055 & 0.068 \\
\hline Cutoff3 & 0.227 & 0.200 & 0.247 \\
\hline Cutoff4 & 1.081 & 0.954 & 1.184 \\
\hline Cutoff5 & 6.322 & 5.581 & 6.990 \\
\hline $\mathrm{N}$ & 1804 & 1804 & 1804 \\
\hline
\end{tabular}

${ }^{*} p<0.05,{ }^{*} p<0.01,{ }^{* * *} p<0.001$ Reference categories: minimum wage, illiterate, White, male, coercive obligation (Model 2). 
Table 5: Fitted probabilities of number of different types of crimes committed for Model 3

\begin{tabular}{|l|c|c|c|c|c|c|c|}
\hline \multicolumn{2}{|c|}{ Fitted probabilities } & \multicolumn{7}{|c|}{ Number of different types of crimes committed } \\
\cline { 2 - 8 } & & $\mathbf{0}$ & $\mathbf{1}$ & $\mathbf{2}$ & $\mathbf{3}$ & $\mathbf{4}$ & $\mathbf{5}$ \\
\hline \multirow{4}{*}{$\begin{array}{l}\text { Consensual/coercive } \\
\text { continuum }\end{array}$} & $-2 \mathrm{SD}$ & 0.251 & 0.310 & 0.242 & 0.141 & 0.045 & 0.010 \\
\cline { 2 - 8 } & $-1 \mathrm{SD}$ & 0.306 & 0.321 & 0.216 & 0.114 & 0.034 & 0.008 \\
\cline { 2 - 8 } & Mean & 0.367 & 0.322 & 0.188 & 0.091 & 0.026 & 0.006 \\
\cline { 2 - 8 } & $+1 \mathrm{SD}$ & 0.432 & 0.312 & 0.160 & 0.072 & 0.020 & 0.005 \\
\cline { 2 - 8 } & + 2SD & 0.500 & 0.293 & 0.132 & 0.056 & 0.015 & 0.003 \\
\hline
\end{tabular}


Figure 1: Predicting normative alignment with the police

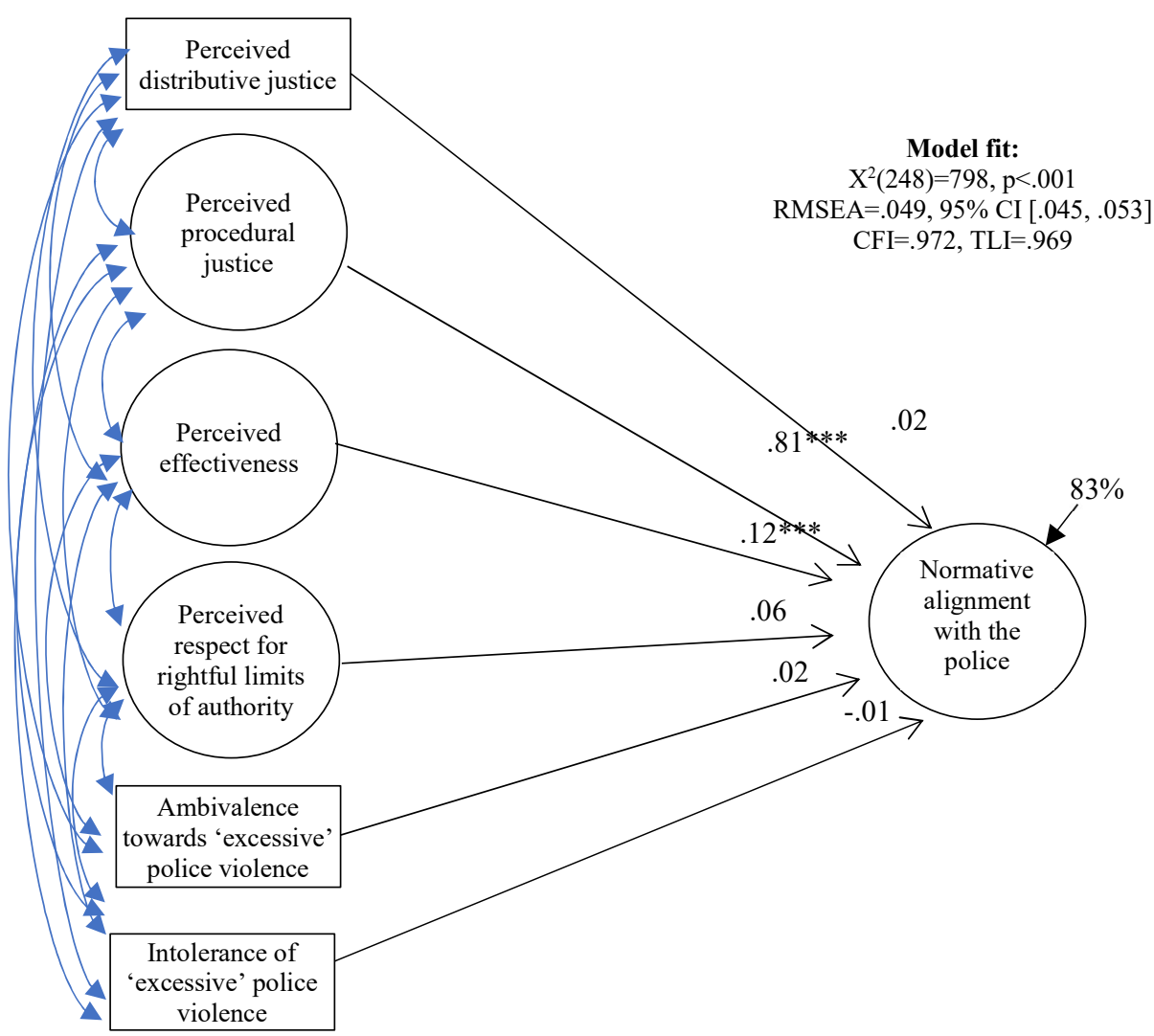

Standardized regression coefficients. Reference category: 'tolerance of police violence'. Controls: gender, age and seven dummy variables regarding the eight areas. 
Figure 2: Standard (left) and new (right) approaches to conceptualizing coercive and consensual authority relations in the context of compliance with the law

Coercive and instrumental authority relations (high to low)
Consensual and normative authority relations (high to low)
Motivations to comply with the law with the law

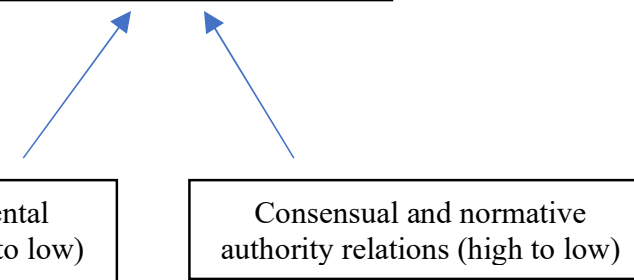

Coercive versus consensual authority relations (coercive to ambivalent to consensual) 


\section{Online supplementary materials}

\section{Appendix A: Overview of the two studies}

Data from both studies were collected as part of two complementary studies that themselves formed part of a larger project conducted by the Center for the Study of Violence of the University of São Paulo (NEV-USP) on police-citizen relations in Brazil's largest city. The first study had a three-wave longitudinal design that aimed to assess the dynamics over time of attitudes towards legal authority among residents of eight selected neighborhoods in the city of São Paulo and was conducted between 2015 and 2018. The second study was a cross-sectional representative sample survey of the population of São Paulo carried out in 2015. The survey instrument used in both studies was the same (although some measures were added and others removed in the second and third waves of the longitudinal survey). Overall, the project partly sought to investigate the extent to which the eight selected neighborhoods could substantively represent the broad population of the city (see Nery et al., 2019; Oliveira et al., 2019). A longitudinal examination about police-citizen relations in São Paulo using all three waves of data of the first study was also conducted by Oliveira (2021), while a preliminary empirical test of procedural justice theory using the cross-sectional survey data of the second study was conducted by Oliveira et al. (2020). In this paper, for study one we drew on data from the second wave of the longitudinal survey to assess the predictors of normative alignment with the police in São Paulo (this was the only wave that included the relevant questions) and for study two, on the cross-sectional survey data to examine the nature of people's duty to obey the police and assess the predictors of selfreported compliance with the law. 
Appendix B: Study one descriptive statistics, measures and scaling

On the basis of gender, age and social class, study one's sample closely matched the São Paulo population as a whole. According to the 2010 Census, $47 \%$ of the city's population were male, $61 \%$ were white, the average age of residents was 36 years old, and 7\% belonged to social class A while 9\% belonged to social classes D and E (social classes are assigned based on the Critério Brasil, an official system of social class assignment from the Brazilian Institute of Geography and Statistics (IBGE) based on respondents' economic positioning and buying power). In study one $46 \%$ of respondents selfidentified as male and $56 \%$ as white, the average age was 42 years old, $9 \%$ belonged to class A (the wealthiest segment of society), $8 \%$ belonged to class B1, $23 \%$ to class B2, $27 \%$ to class $\mathrm{C} 1,24 \%$ to class $\mathrm{C} 2$, and $9 \%$ to classes $\mathrm{D}$ and $\mathrm{E}$.

Because we used the second wave of a panel survey, we analyzed the extent to which the attrition rate introduced bias into the sample, estimating a binomial logistic regression model predicting the odds of dropping out between waves one and two. No demographic (gender, age, race, and social class) or attitudinal (normative alignment with the police, procedural justice, police effectiveness, and fear of the police) variables were significant predictors of dropping out (please contact the first author for details). On this basis, dropouts can be seen to be roughly missing at random.

Table B1 provides details of the core measures, translated into English by one of the Brazilian co-authors. Table B2 provides the measures in Portuguese. As discussed in the paper, we define legitimacy along two connected lines: (1) the belief that the institution has the moral right to power and (2) feel a moral duty to obey the police (Tyler, 2006a, 2006b). Study one focuses on the first part of legitimacy in study one, which we operationalize as normative alignment (Jackson et al., 2012, 2013; Bradford et al., 2014a, 2014b). Normative alignment was measured by asking respondents whether they thought that police officers generally act in ways that align with their own expectations and values. This operationalization strategy assumes that positive answers to these questions indicate the ascribed normative justifiability of power, i.e. the belief that the institution has the moral right to power because officers wield power in normatively appropriate ways. Conversely, negative answers to these questions are assumed to reflect the opposite, i.e. the belief that the institution lacks the moral right to power because officers wield their power in normatively inappropriate ways.

Table B1: Measures used in study one (translated into English)

\begin{tabular}{|c|c|c|c|}
\hline Construct & Items & $\begin{array}{l}\text { Mean, } \\
\text { standard } \\
\text { deviation } \\
\end{array}$ & Response alternatives \\
\hline $\begin{array}{l}\text { Normative } \\
\text { alignment }\end{array}$ & $\begin{array}{l}\text { How often do police in your neighborhood: } \\
\text { - Act according to what you believe is right? } \\
\text { - } \quad \text { Have the same expectations you have about your community? } \\
\text { - Defend values that are important to a person like you? }\end{array}$ & $\begin{array}{l}3.1,1.3 \\
3.0,1.3 \\
3.3,1.3\end{array}$ & \multirow{4}{*}{$\begin{array}{l}\text { Never } \\
\text { Rarely } \\
\text { Sometimes } \\
\text { Very often } \\
\text { Always }(1-5)\end{array}$} \\
\hline $\begin{array}{l}\text { Procedural } \\
\text { justice }\end{array}$ & $\begin{array}{l}\text { How often do police in your neighborhood: } \\
\text { - } \quad \text { Explain clearly why they pull over or arrest someone? } \\
\text { - } \quad \text { Make impartial and just decisions? } \\
\text { - } \quad \text { Treat people with respect? }\end{array}$ & $\begin{array}{l}2.8,1.5 \\
3.1,1.2 \\
3.3,1.3 \\
3.7,1.3\end{array}$ & \\
\hline $\begin{array}{l}\text { Distributive } \\
\text { justice }\end{array}$ & $\begin{array}{l}\text { How often do police in your neighborhood: } \\
\text { - Treat all people, rich or poor, black or white, equally? }\end{array}$ & $2.9,1.4$ & \\
\hline $\begin{array}{l}\text { Bounded } \\
\text { authority }\end{array}$ & $\begin{array}{l}\text { How often do police in your neighborhood: } \\
\text { - Accept bribes? } \\
\text { - } \quad \text { Protect drug dealers? } \\
\text { - Act as if above the law? }\end{array}$ & $\begin{array}{l}3.0,1.3 \\
3.3,1.4 \\
2.8,1.4\end{array}$ & \\
\hline Effectiveness & $\begin{array}{l}\text { How effective are the police in your neighborhood at: } \\
\text { - Reducing drug trades? } \\
\text { - } \quad \text { Reducing armed robbery? } \\
\text { - } \quad \text { Responding to emergency calls (190)? } \\
\text { - } \quad \text { Crimininal investigation? } \\
\text { - Marches and protests? } \\
\text { - Keeping neighborhood safe? }\end{array}$ & $\begin{array}{l}2.5,1.2 \\
2.7,1.3 \\
3.0,1.3 \\
2.8,1.3 \\
2.7,1.3 \\
2.8,1.3 \\
3.0,1.2\end{array}$ & $\begin{array}{l}\text { Very bad } \\
\text { Bad } \\
\text { Neither good nor bad } \\
\text { Good } \\
\text { Very good (1-5) }\end{array}$ \\
\hline $\begin{array}{l}\text { Violence } \\
\text { vignettes }\end{array}$ & $\begin{array}{l}\text { The police are called after a motorcycle is robbed. Officers identify the } \\
\text { suspects and chase one of them down. Suspect tries to hide in a dark } \\
\text { alley, but officers catch and arrest him. By radio, officers learn the }\end{array}$ & $1.6,1.1$ & $\begin{array}{l}\text { Very poor } \\
\text { Poor } \\
\text { Neither good nor bad }\end{array}$ \\
\hline
\end{tabular}




\begin{tabular}{|l|l|c|}
\hline & $\begin{array}{l}\text { suspect in custody was already a justice fugitive who had previously } \\
\text { been condemned for drug trafficking and murder. Officers then release } \\
\text { him, tell him to run away, and then shoot him in the back. He dies } \\
\text { immediately. }\end{array}$ & $\begin{array}{c}\text { Good } \\
\text { Euring a demonstration with thousands of people demanding } \\
\text { improvements for the city, some protesters start to destroy storefronts' } \\
\text { glass doors and throw litter bins on fire. Officers who were standing by } \\
\text { the protest intervene using rubber bullets and tear gas on all protesters. } \\
\text { Protesters begin to run away, and underneath the smoke a young woman } \\
\text { is shot in the eye with a rubber bullet, thereby losing her vision for life. }\end{array}$ \\
$\begin{array}{l}\text { Officers catch a man in the act and arrest him for drug trafficking. } \\
\text { Before taking him to the police station, they decide to go to the } \\
\text { arrestee's place with no warrants in order to look for more evidence. } \\
\text { There, officers torture him so that he would tell them where he keeps } \\
\text { the rest of the drugs and give his partners' names. }\end{array}$ & $2.1,1.2$ \\
\hline
\end{tabular}

The goal of study one was to estimate the predictors of variation in normative alignment, which we take to mean to assess the criteria that people use to judge whether they feel the police act appropriately (what do people mean when they say that defend their views, act in ways they believe Is appropriate, and share their expectations about the community?).

The five potential predictors of normative alignment were procedural justice, distributive justice, bounded authority, effectiveness, and tolerance of 'excessive' police violence. Procedural justice was measured using items designed to capture fair interpersonal treatment, neutral decisionmaking, explaining decisions and allowing the citizen voice in interactions with the police (Tyler \& Jackson, 2014). Bounded authority items addressed perceptions of corruption and acting as if they are above the law (Trinkner et al., 2018). Effectiveness indicators captured crime reduction, responding to emergencies, investigating crime, and keeping order on the streets (Reisig et al., 2007). Tolerance of 'excessive' police violence was measured using three vignettes: the first involving the killing of a suspect, the second involving the shooting of a protestor using rubber bullets, and the third involving the torturing of a drug dealer to gain information.

The single indicator of distributive justice deserves comment. Distributive justice was measured by asking about perceived equal police treatment of two different social groups ("How often do police in your neighborhood: Treat all people, rich or poor, black or white, equally?"). On the one hand, interpersonal treatment is central to procedural justice, so the use of the word 'treat' to some degree fuses procedural and distributive justice. On the other hand, the question addresses differential treatment across aggregate social groups rather than the fairness or unfairness of treatment of everybody (whomever they are). This is similar to Fine et al.'s (2021) measures of distributive justice/bias from the Crossroads Study: "Police treat males and females differently", "Police treat people differently depending how old they are", "Police treat people differently depending on their race/ethnic group", and "Police treat people differently depending on the neighborhoods they are from." Notably, Fine et al. (2021) used confirmatory factor analysis and found that distributive justice (thus measured) was empirically distinct to procedural justice.

It is also worth mentioning the generality of the word 'treat' in the distributive justice measure. Procedural justice indicators are typically more specific, outlining what fair interpersonal treatment means, e.g. "During your last contact with the police when you were accused of a crime, how much of your story did the police let you tell?" and "Think back to the last time the police accused you of doing something wrong, did the police treat you with respect and dignity or did they disrespect you?' (Fine et al., forthcoming). Because our measure of distributive justice is less specific than that ('treat differently' or 'treat equally'), respondents who think (for instance) that poor people are treated worse than rich people may be thinking that poor people get less protection than rich people, get worse service, are policed more aggressively, and so forth. If this is the case, then a respondent who believes that poor people get worse treatment from the police than rich people may believe that the police are allocating some of the 'goods' and 'bads' unequally (e.g. unequal service, protection, aggressive regulation and other distributive outcomes) across social groups. This would be consistent with our conceptual definition of distributive justice. We discuss this issue in the limitations section at the end of the paper.

As noted by one of the anonymous referees, we should acknowledge that some prior studies have operationalised distributive justice as perceived outcome satisfaction/fairness rather than perceptions of the fairness of the distribution of the benefits and burdens of scarce resources across 
aggregate social groups in society (e.g. McLean, 2020). For example, Solomon \& Cheane (2021) presented research participants with videos of police-citizen interactions and measured distributive justice by asking whether people thought the outcome was fair, deserved, and lawful. Some of Tyler's early work also approached distributive justice as outcome fairness and deservingness. Tyler and Caine (1981) asked individuals 'Did the student receive the grade they deserved?' and 'Do you receive the outcomes you deserve?'. Tyler, Casper and Fisher (1989) asked research participants 'how does your sentence compare to that received by others who have committed the same crime?'. Tyler, Rasinski and McGraw (1985) asked respondents 'Do you feel that you receive a fair number of benefits or that you receive more or fewer benefits than you deserve?'. Tyler \& Schuller (1990) asked people 'How fair was the outcome you received?' and Tyler \& Blader (2010) asked participants 'How fair are the outcomes that you receive from your work organization?'. 'how fair are the outcomes that you receive from your work supervisor?', 'Do you think that the pay and benefits you receive are more than you deserve, less than you deserve, or are about fair?' and 'Do you think that the outcomes you receive from your supervisor are more than you deserve, less than you deserve, or are about fair?'

Importantly for the current study, Tyler's later work moved away from measuring distributive justice as perceived individual outcome fairness/deservingness/satisfaction, towards measuring distributive justice as perceptions of the fair distribution of process and outcome across aggregate social groups, e.g. 'The police do not provide the same quality of service to people living in all areas of the city', 'Minority residents of the city receive a lower quality of service from the NYPD than do whites', 'The police treat everyone equally regardless of their race' and 'The police provide better services to the wealthy' (Sunshine \& Tyler, 2003). To assess (among other things) whether distributive justice, thus measured, is empirically distinct from procedural justice, Reisig et al. (2017) tapped into distributive justice using the following five items: 'Provide the same quality of service to all citizens', 'Enforce the law consistently when dealing with all people', 'Make sure citizens receive the outcomes they deserve under the law', 'Give minorities less help because of their race', and 'Provide better services to wealthier citizens'. They found that these items loaded on a different underlying factor than procedural justice indicators.

It is also worth saying that defining distributive justice with respect to the fair allocation of the burdens and benefits of policing across aggregate social groups is consistent with work in political philosophy, where theories of distributive justice typically coalescence around the fairness of who gets what and why, at scale (see, for example, Von Platz, 2020). How should social and economic institutions be designed to maximise the benefits and burdens of social cooperation, especially when people have competing needs or claims? Should deserving people/social groups be rewarded in accordance with their merits? Should distributive justice be about putting in place principles that regulating the balance of individual interest and claims to the wide range of social cooperation benefits? What about the different objects of distributive justice (e.g. economic, racial justice, education)? Should 'goods' and 'bads' be differentially distributed across different groups, in the context of social welfare, criminal justice, etc? 
Table B2: Measures used in study one (in Portuguese)

\begin{tabular}{|c|c|c|}
\hline Construct & Items & Response alternatives \\
\hline $\begin{array}{l}\text { Normative } \\
\text { alignment }\end{array}$ & $\begin{array}{l}\text { A polícia no seu bairro: } \\
\text { - } \quad \text { Age de acordo com o que o(a) sr(a) acha que é certo? } \\
\text { - Tem as mesmas expectativas que você sobre a sua comunidade? } \\
\text { - } \quad \text { Defende valores que são importantes para uma pessoa como você? }\end{array}$ & \multirow{4}{*}{$\begin{array}{l}\text { Nunca } \\
\text { Raramente } \\
\text { Às vezes } \\
\text { Quase sempre } \\
\text { Sempre (1-5) }\end{array}$} \\
\hline $\begin{array}{l}\text { Procedural } \\
\text { justice }\end{array}$ & $\begin{array}{l}\text { A polícia no seu bairro: } \\
\text { - } \quad \text { Explica claramente por que revista ou prende as pessoas? } \\
\text { - } \quad \text { Toma decisões que são justas e imparciais? } \\
\text { - } \quad \text { Dá atenção às informações que as pessoas trazem? } \\
\text { - } \quad \text { Trata bem pessoas como você? }\end{array}$ & \\
\hline $\begin{array}{l}\text { Distributive } \\
\text { justice }\end{array}$ & $\begin{array}{l}\text { A polícia no seu bairro: } \\
\text { - Trata com respeito todas as pessoas: ricos e pobres, negros e } \\
\text { brancos? }\end{array}$ & \\
\hline $\begin{array}{l}\text { Bounded } \\
\text { authority }\end{array}$ & $\begin{array}{l}\text { Pelo que o(a) sr(a) sabe ou ouviu falar: } \\
\text { - Os policiais do bairro aceitam suborno? } \\
\text { - Os policiais protegem os traficantes de drogas? } \\
\text { - Os policiais agem como se estivessem acima da lei? }\end{array}$ & \\
\hline Effectiveness & $\begin{array}{l}\text { Como o(a) sr(a) avalia o trabalho da polícia no seu bairro em relação } \\
\text { à/ao: } \\
\text { - Diminuição do tráfico de drogas? } \\
\text { - } \quad \text { Diminuição do assalto à mão armada? } \\
\text { - Atendimento às chamadas de emergências (190)? } \\
\text { - Atendimento na delegacia de polícia? } \\
\text { - Investigação de crimes? } \\
\text { - Manifestações / protestos? } \\
\text { - Manter as ruas do bairro tranquilas? }\end{array}$ & $\begin{array}{l}\text { Muito ruim } \\
\text { Ruim } \\
\text { Nem bom, nem ruim } \\
\text { Bom } \\
\text { Muito bom }(1-5)\end{array}$ \\
\hline $\begin{array}{l}\text { Violence } \\
\text { vignettes }\end{array}$ & $\begin{array}{l}\text { A polícia é acionada após o roubo de uma moto e passa a perseguir um } \\
\text { dos envolvidos. O rapaz tenta se esconder em uma viela escura, mas é } \\
\text { rendido por policiais que o algemam. Pelo radio os policiais descobrem } \\
\text { que o rapaz já havia sido condenado por tráfico e homicídio e é fugitivo } \\
\text { da justiça. Os policiais então soltam o rapaz, mandam ele correr e } \\
\text { atiram contra ele. O rapaz more no local. } \\
\text { Durante uma passeata com milhares de pessoas exigindo melhorias na } \\
\text { cidade, alguns dos participantes quebram vitrines e colocam fogo em } \\
\text { lixeiras. A polícia, que vinha acompanhando o protesto, intervém para } \\
\text { dispersá-lo, lançando bombas de gás lacrimogêneo e atirando balas de } \\
\text { borracha contra toda a multidão envolvida no protesto. Em meio à } \\
\text { fumaça os manifestantes correm, uma jovem é atingida no olho e perde } \\
\text { a visão. } \\
\text { Policiais prendem em flagrante um homem acusado de tráfico de } \\
\text { Drogas. Antes de leva-lo para a delegacia, os policiais decidem sem } \\
\text { mandato ir até a casa do acusado em busca de mais provas. Na casa, os } \\
\text { policiais torturam o homem para que ele indique onde guarda as drogas } \\
\text { e entregue outros comparsas. }\end{array}$ & $\begin{array}{c}\text { Péssima } \\
\text { Ruim } \\
\text { Nem boa, nem ruim } \\
\text { Boa } \\
\text { Excelente (1-5) }\end{array}$ \\
\hline
\end{tabular}




\section{Appendix C: Confirmatory factor analysis}

We used MPlus 7.2 to fit a four factor CFA model (including distributive justice as a single indicator in the fitted model). All manifest indicators we set to be ordinal categorical variables and all latent constructs and the single indicator of distributive justice were allowed to covary. The approximate fit statistics suggested that the model fitted the data adequately (RMSEA $=0.039$, RMSEA $_{\mathrm{C} 190 \%}=[0.33$, 0.045]; CFI $=0.980, \mathrm{TLI}=0.987$ ). The factor loadings and $\mathrm{R}^{2}$ statistics were fairly strong for all the measures, indicating reasonable scaling properties (procedural justice: $\lambda=0.71$ to $0.78, R^{2}=0.51$ to 0.61 ; effectiveness: $\lambda=0.67$ to $0.83, \mathrm{R}^{2}=0.45$ to 0.69 ; bounded authority: $\lambda=0.61$ to $0.72, \mathrm{R}^{2}=0.37$ to 0.52 ; normative alignment: $\lambda=0.85$ to $0.90, \mathrm{R}^{2}=0.72$ to 0.80 ).

Table $\mathrm{C}$ provides the correlation matrix estimated within the CFA model. Although empirically distinct, the constructs were all positively correlated, e.g. procedural justice and distributive justice $(r=.76)$, distributive justice and effectiveness $(r=.50)$. The extremely strong positive correlation between procedural justice and normative alignment $(r=.91)$ is worth commenting on. While the appropriate fit statistics supported the idea that these are empirically distinct latent constructs (see the next paragraph), it does seem that procedural justice (explaining and making impartial decisions, listening to people, and treating people with respect is collectively) is an extremely important criterion that people use when drawing conclusions about whether the police act appropriately, have similar expectations about their community, and defend values that are important to them.

Table C: Correlation matrix between four latent constructs plus distributive justice

\begin{tabular}{|l|c|c|c|c|c|}
\hline & $\begin{array}{c}\text { Procedural } \\
\text { justice }\end{array}$ & $\begin{array}{c}\text { Normative } \\
\text { alignment }\end{array}$ & $\begin{array}{c}\text { Police } \\
\text { effectiveness }\end{array}$ & $\begin{array}{c}\text { Bounded } \\
\text { authority }\end{array}$ & $\begin{array}{c}\text { Distributive } \\
\text { justice }\end{array}$ \\
\hline Procedural justice & 1 & & & & \\
\hline Normative alignment & .91 & 1 & & & \\
\hline Police effectiveness & .66 & .66 & 1 & & \\
\hline Bounded authority & .27 & .21 & .24 & 1 & \\
\hline Distributive justice & .76 & .69 & .50 & .23 & 1 \\
\hline
\end{tabular}

To further investigate the distinctiveness of normative alignment and procedural justice, as measured, we estimated two confirmatory factor analysis models: a two-factor model in which procedural justice and normative alignment were two correlated but distinct latent constructs; and a one-factor model in which all items tapped into a single construct. Even though both solutions fitted the data well (with acceptable model fit statistics), the two-factor solution had a better model fit (i.e., higher CFI and TLI, and lower RMSEA), suggesting that perceived procedural justice and normative alignment with the police were two highly correlated but empirically distinct latent constructs (please contact the first author for details). 
Appendix D: Latent class analysis of people's attitudes towards 'excessive' police violence We used latent class analysis (LCA) to assess the underlying structure of research participants' levels of approval or disapproval of 'excessive' police use of force. We specified the indicators as ordered categorical variables (again using MPlus 7.2). We used LCA because it allows us to identify patterns of responses to the three vignettes to create mutually exclusive classes of homogenous groups with similar response patterns. LCA is a model-based approach, unlike traditional cluster analysis techniques, and there are formal criteria for choosing the optimal number of classes. The vignettes describe different situations (excessive use of force against student protestors, search without a warrant and torture of a suspect, and murder of a suspect in custody) that may or may not represent increasingly serious (and may or may not be equally spaced in terms of perceived seriousness) scenarios in the eyes of respondents. Given the different nature of the three vignettes and the lack of prior work on this issue, it was also not clear how many underlying groups will emerge in terms of approval, ambivalence or disapproval of all or some of the different behaviours. Using LCA allowed us to assess the number of underlying latent categories, as well as the ways in which approval of each scenario relate to those latent categories (via juxtaposing each variable's categories to the probability of belonging to a certain class).

We chose LCA over latent trait analysis - i.e. we represented the latent quantity as categorical (homogenous groups of individuals based on similar attitudes towards police violence) rather than linear (an underlying continuum, where presumably people who disapprove of the violent events are placed at one end, and people who approve of the violent events are placed at one end) - in part because we had an intuition that the latent quantities might best be represented as groups (different types of people with different configurations of attitudes towards police violence) rather than some fine-grained underlying continuum. LCA also allowed us to use dummy variables when modelling the predictors of self-reported legal compliance and not assume monotonicity when interpreting the partial regression coefficients predicting normative alignment. For example, the 'ambivalent' group could have similar fitted levels of compliance to the 'intolerant group', while the 'tolerant group' could have different fitted levels of compliance to both those groups (adjusting for the other factors in the model). If we had used linear factor analysis to create an index of (dis)approval of 'excessive' police violence, we would not have had this flexibility.

When deciding the number of classes, researchers generally rely upon three considerations (Nylund, Asparouhov, and Muthén, 2007): (1) model fit statistics, in particular the likelihood-ratio (LR) tests and model fit indices gauging how well the model represents the data, (2) the entropy of the model and the average latent class probabilities, establishing whether clear delineation of classes is feasible, and (3) substantive considerations, or in other words, whether the derived classes make sense. From the three models, the 4-class solution was the least preferable option (Table D1). The bootstrapped LR-test was not statistically significant, implying that the model did not improve upon the 3-class solution, and the BIC (Bayesian Information Criterion) value was the highest, which indicates the worst fit. Entropy represents how well the LCA model differentiates between the latent classes, with values closer to one representing better solutions. By comparison, the average latent class probabilities quantify how precisely units can be assigned to their classes. On these two statistics, the 4-class solution did not perform well either, with the entropy being lower compared to the 3-class solution, and the average latent class probabilities being the lowest across the models.

Table D1: Model fit comparison of the latent class analysis

\begin{tabular}{l|cc|cc|} 
Number of classes & Bootstrapped LR-test & BIC & Entropy & $\begin{array}{c}\text { Average latent class } \\
\text { probability }\end{array}$ \\
\hline 2-class solution & LR=-2570.616, $<<0.001$ & 5204.419 & 0.387 & $0.757-0.844$ \\
3-class solution & $\mathrm{LR}=-2537.210, \mathrm{p}>0.05$ & 5253.214 & 0.670 & $0.724-0.883$ \\
4-class solution & $\mathrm{LR}=-2527.503, \mathrm{p}>0.05$ & 5310.437 & 0.635 & $0.466-0.944$ \\
\hline
\end{tabular}

On the one hand, then, from the 2- and 3-class solutions, the 2-class solution had the better model fit statistics according to the BIC and the 3-class model did not appear to be significantly better than the 2-class one (although it comes close with $\mathrm{p}=0.072$ ). On the other hand, both the entropy and latent class probabilities favored the 3-class approach with higher entropy and slightly higher average class probabilities. These apparently contradictory test statistics can be explained by looking at the emergent latent classes in the 3-class model (Table D2), where one of the classes was much smaller than the other two. Tests of global fit and model comparisons tend to be sensitive to imbalances in class 
sizes and the presence of a small but distinctive class can make it appear as if the 2-class solution performed better. All things considered, we view the 3-class model to be more appropriate, particularly because it also makes more sense from a theoretical point of view.

Table D2: Latent Class Analysis results in probability scales for each police vignette

\begin{tabular}{|c|c|c|c|c|}
\hline \multirow[b]{2}{*}{ Variable } & \multirow[b]{2}{*}{ Response alternatives } & \multicolumn{3}{|c|}{ LCA results in probability scale } \\
\hline & & $\begin{array}{c}\text { "Ambivalent towards } \\
\text { violence" }\end{array}$ & $\begin{array}{l}\text { "Tolerant of } \\
\text { violence" }\end{array}$ & $\begin{array}{c}\text { "Intolerant of } \\
\text { violence" }\end{array}$ \\
\hline \multirow{5}{*}{$\begin{array}{l}\text { Murder of a } \\
\text { suspect in custody }\end{array}$} & Very poor & 0.563 & 0.171 & 0.958 \\
\hline & Poor & 0.240 & 0.171 & 0.006 \\
\hline & Neither good nor bad & 0.105 & 0.204 & 0.016 \\
\hline & Good & 0.060 & 0.296 & 0.019 \\
\hline & Excellent & 0.032 & 0.158 & 0.000 \\
\hline \multirow{5}{*}{$\begin{array}{l}\text { Excessive use } \\
\text { against student } \\
\text { protesters }\end{array}$} & Very poor & 0.310 & 0.155 & 0.733 \\
\hline & Poor & 0.294 & 0.209 & 0.097 \\
\hline & Neither good nor bad & 0.248 & 0.135 & 0.105 \\
\hline & Good & 0.148 & 0.261 & 0.036 \\
\hline & Excellent & 0.000 & 0.239 & 0.030 \\
\hline \multirow{5}{*}{$\begin{array}{l}\text { Search without a } \\
\text { warrant and torture } \\
\text { of a suspect }\end{array}$} & Very poor & 0.186 & 0.000 & 0.757 \\
\hline & Poor & 0.369 & 0.000 & 0.051 \\
\hline & Neither good nor bad & 0.310 & 0.040 & 0.023 \\
\hline & Good & 0.135 & 0.453 & 0.083 \\
\hline & Excellent & 0.000 & 0.507 & 0.085 \\
\hline$N$ & & 468 & 74 & 385 \\
\hline$\%$ & & $50.5 \%$ & $8.0 \%$ & $41.5 \%$ \\
\hline
\end{tabular}

The best way to understand the three emergent latent classes is to juxtapose each variable's categories to the probability of belonging to a certain class (Table D2). We named the biggest group $(\mathrm{n}=468)$ in the 3-class model "ambivalent towards violence" because, while people belonging to this class generally disapproved of excessive police use of force, a minority were either undecided or willing to approve of excessive police violence. We named the second and smallest $(\mathrm{n}=74)$ class "tolerant of violence" because in this group the majority of people were either undecided regarding the use of excessive police violence or approved of it. Finally, we named the third group "intolerant of violence" $(\mathrm{n}=385)$. In this group, in each variable at least approximately three-fourths of the respondents found the way the police handled the described scenarios 'very poor'. 
Appendix E: Details of the thematic analysis

For the thematic analysis, a coding scheme was devised with six distinct steps as shown by the flowchart (Figure E). Further details regarding the coding are available from the first author.

Figure E: Outline of the thematic analysis carried out responses to the open-ended question

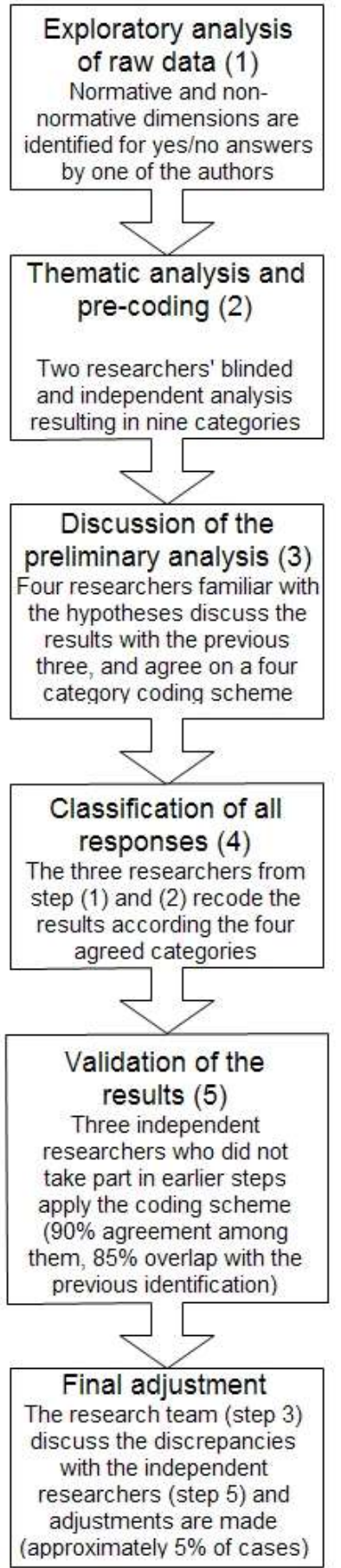


Appendix F: Measures and analytical strategy for study two

To measure obligation to obey the police, we asked a closed-ended measure ("Do you think you have a duty to obey the police even when you believe they are wrong?" with binary "yes" or "no" response alternatives) and followed this up with an open-ended question ("Why do you think you have/do not have a duty to obey the police even if you believe the police is wrong?"). We used thematic analysis on the open-ended question (see Appendix E).

Normative alignment with the police was measured using a single indicator: "The police act according to what I believe is right", (1) never to (5) always. Personal fear of the police was measured by asking people: "Are you afraid of the police?", with three responses of "no", "undecided" and "yes". General fear of the police was measured by asking people "How often would you say that people are afraid of the police?", "never" to "always" on a 1 to 5 Likert-scale. Please contact the first author for study two's measures in Portuguese.

We used latent trait analysis (LTA) to assess the scaling properties of the different motives to obey or disobey the police, normative alignment, and fear of police. In addition to answers to the closed-ended obligation question (binary) and the categories derived based on the open-ended followup (nominal), we included in the latent trait modelling normative alignment (ordinal) and general and personal fear of the police (ordinal). We tested whether a two or a one latent trait model fitted the data best (see Appendix G), with the two trait model designed to potentially distinguish between instrumental and normative police-citizen relations, and the one trait model potentially placing instrumental factors at one end (fear of the police, normative motives to disobey the police, instrumental motives to obey the police, and the absence of normative alignment) and normative factors at the other end (fear of police, normative motivations to obey the police, and the presence of normative alignment).

We then used the resulting measurement model to predict self-reported compliance with the law, adjusting for personal morality. To measure personal morality of the particular illegal acts, five questions were asked: "Do you think it is right or wrong that people: (i) try to bribe a traffic warden to avoid a fine?; (ii) buy counterfeit goods?; (iii) use cable TV signal without paying for it?; (iv) buy goods without a receipt to pay less?; and (v) pay for a private doctor or a private dentist without a receipt?". Answers were either "right" or "wrong". To measure compliance with the law, these same five items were asked, but respondents were asked whether they had ever done each of these five things. Response alternatives were either "yes" and "no" . For both personal morality and offending the "no" and "wrong" answers were coded as 0 , and the "yes" and "right" answers as 1 . We summed the responses for each scale, creating two six category variables representing offending behavior and (associated) personal morality judgements. These are both "variety" scales, in that they are summed dichotomous category scales that indicate the number of type of crimes people have committed and the number of type of crimes that people think are wrong (for discussion see Sweeten, 2012).

Finally, we assessed whether measures of obligation to obey and the coercive to consensual continuum scale predicted self-reported offending behavior, adjusting for geographical region, gender (self-identified male or female), age, income (with regards to the minimum wage, six categories), education (seven categories), self-reported racial identification (White, Black, Mixed White and Black, Asian-descendant, and Indigenous ${ }^{3}$ ) and personal morality. Missing data was an issue - in some cases pursuing complete case analysis would have resulted in losing almost quarter of the data - so we used chained equation multiple imputation (Lall, 2016; Lang \& Wu, 2017; von Hippel, 2009). Based on the nature of the outcome variable, ordered logistic regression models were fitted with clustered robust standard errors for the regions considering the clustering of the sampling design. ${ }^{4}$ To make various comparisons, we specified legitimacy in the fitted models according to the three stages outlined above: (1) as a simple yes/no binary variable of duty to obey, (2) as the different categories created based on

\footnotetext{
${ }^{3}$ Racial self-identification was measured using the official racial classifications in Brazil based on the Brazilian Institute of Statistics and Geography (IBGE). This involves five categories following the survey question "What is your color or race?": Branca (White - Caucasian), Preta (Black - Afro-descendant), Parda (Mixed Race), Amarela (Yellow - Asian-descendant), and Indígena (Indigenous - Native Brazilians).

${ }^{4}$ Alternative link functions (i.e. negative binomial and poisson) were also used. The ordinal regression model fitted the data better according to AIC and BIC. To test the robustness of our results, we fitted the models with the partial proportional odds assumption (Peterson and Harrell, 1990; Williams, 2006). In such models, the parallel odds assumption was tested for each variable in the model, and for the subset it did not apply to, multinomial logistic model was fitted instead. However, these models only provided marginal improvement compared to the ones presented in the paper, and only for a single variable, personal morality. Furthermore, the substantive findings remained unchanged. Please contact the first author for details.
} 
combining the closed-ended and open-ended responses of duty to obey, and (3) as a single latent trait, with normative considerations at one end, and instrumental considerations at the other. 


\section{Appendix G: Latent trait analysis}

We fitted a two-trait model first, based on the possibility that people differentiate between instrumental and normative considerations. The specified model linked one latent trait to the original duty to obey variable, the two consensual content analysis categories (i.e. acceptance of rightful authority and disobedient protest), and an item tapping into normative alignment with the police, and the other latent trait to the original duty to obey variable, the two prudential content analysis categories (rejection of rightful authority and coercive obligation), and two items regarding personal and general fear of police (Figure G1). The two latent traits were allowed to correlate with one another. To make the relative contribution of each variable comparable, the coefficients reported here were standardized by the corresponding continuous latent variable's variance, quantifying relative influence of the nominal, binary, and ordinal variables for each trait (this, however, does not permit other aspects of cross-model comparison).

Figure G1: Two latent traits for normative and instrumental considerations

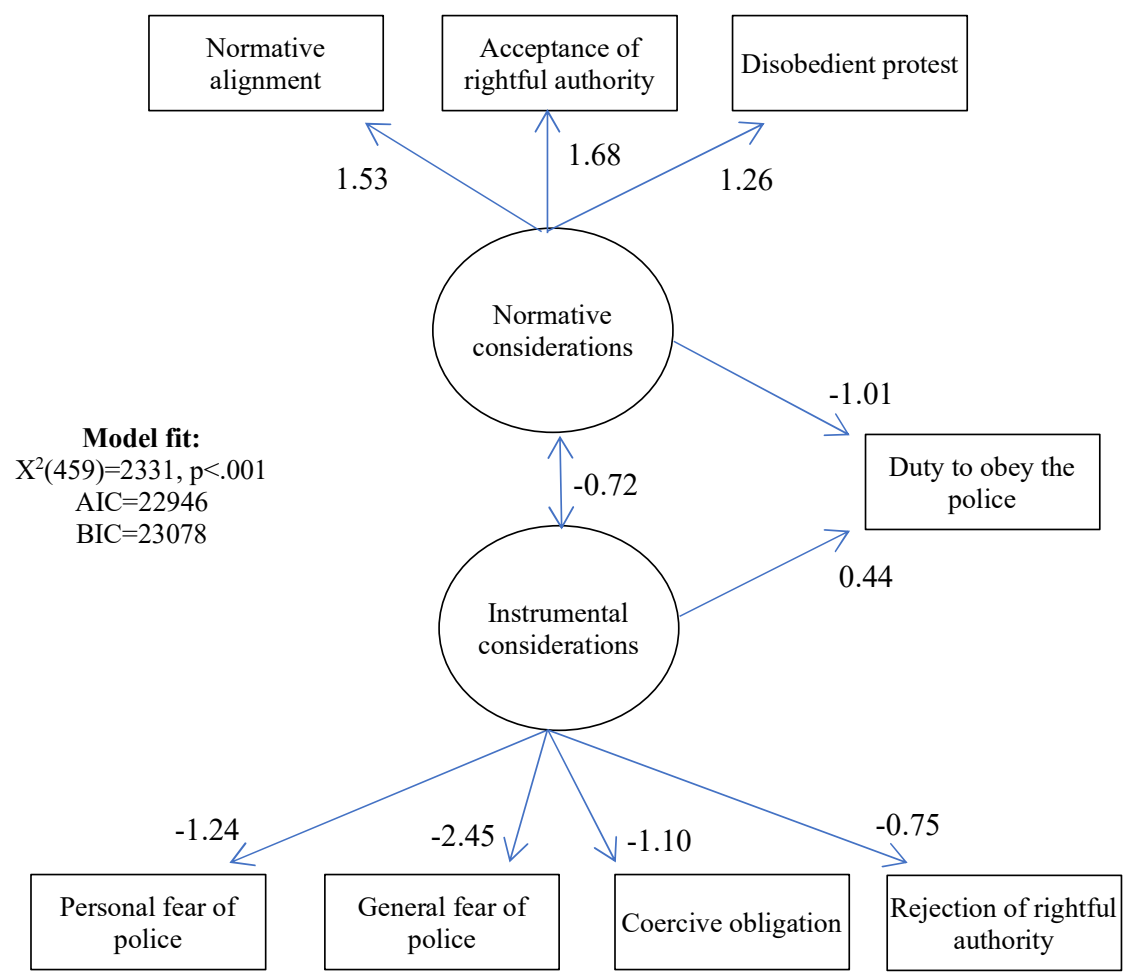

The results for the two-trait solution are shown in Figure G1 (for Figures G1 and G2 all pathways were significant on the $0.01 \%$ level) Given the findings, we label the first latent trait 'normative considerations' and we label the second latent trait 'instrumental considerations'. For the normative considerations trait, acceptance of rightful authority had the strongest positive loading $\left(\lambda_{\text {accept_norm }}=1.68\right)$, then normative alignment $\left(\lambda_{\text {normative_norm }}=1.53\right)$, and disobedient protest $\left(\lambda_{\text {disobprot_norm }}=1.26\right)$. The trait loading of the original duty to obey variable was weaker $\left(\lambda_{\text {obey_norm }}=-1.01\right)$. For the instrumental considerations trait, all of the trait loadings were negative, as an indication of the negative association between the two latent traits. General fear of police had the strongest trait loading $\left(\lambda_{\text {genfear_coerc }}=-2.45\right)$, followed by personal fear of police $\left(\lambda_{\text {persfear_coerc }}=-1.24\right)$, the coercive category $\left(\lambda_{\text {coerc_coerc }}=-1.10\right)$, rejection of rightful authority category $\left(\lambda_{\text {rejaut_coerc }}=-0.75\right)$, and finally, the original duty to obey variable $\left(\lambda_{\text {obey_coerc }}=0.44\right)$. Being afraid of the police was the strongest indicator of instrumental considerations, followed by the duty to obey related constructs. Yet, it is notable that general fear of the police contributed almost twice as much to the latent trait compared to personal fear of the police, twice as much compared to the coercive category, and more than three times as much compared to the rejection of rightful authority category, and more than five times as much as the original duty to obey variable.

We then tested whether instrumental and normative considerations might be represented as a single underlying dimension. The motivation was twofold. First, there was the high correlation between the two latent traits $(\mathrm{r}=-0.72)$. Second, findings presented in the paper indicated significant ambivalence in some people's attitudes towards the police (see the bivariate correlations reported in Tables 2 and 3). 
We fitted a single trait model that incorporated all the observed variables described above. The fitted model is shown in Figure G2. General fear of police has the strongest trait loading $\left(\lambda_{\text {genfear_polleg }}=-2.60\right)$, followed by normative alignment $\left(\lambda_{\text {moral } \text { polleg }}=1.58\right)$, personal fear of police $\left(\lambda_{\text {persfear_polleg }}=-1.12\right)$, acceptance of rightful authority $\left(\lambda_{\text {accept polleg }}=1.07\right)$, disobedient protest $\left(\lambda_{\text {disobprot_polleg }}=0.71\right)$, duty to obey $\left(\lambda_{\text {obey_polleg }}=-0.57\right)$, and rejection of rightful authority $\left(\lambda_{\text {rejaut_polleg }}=0.28\right)$.

Figure G2: Single latent trait, the coercive to consensual continuum

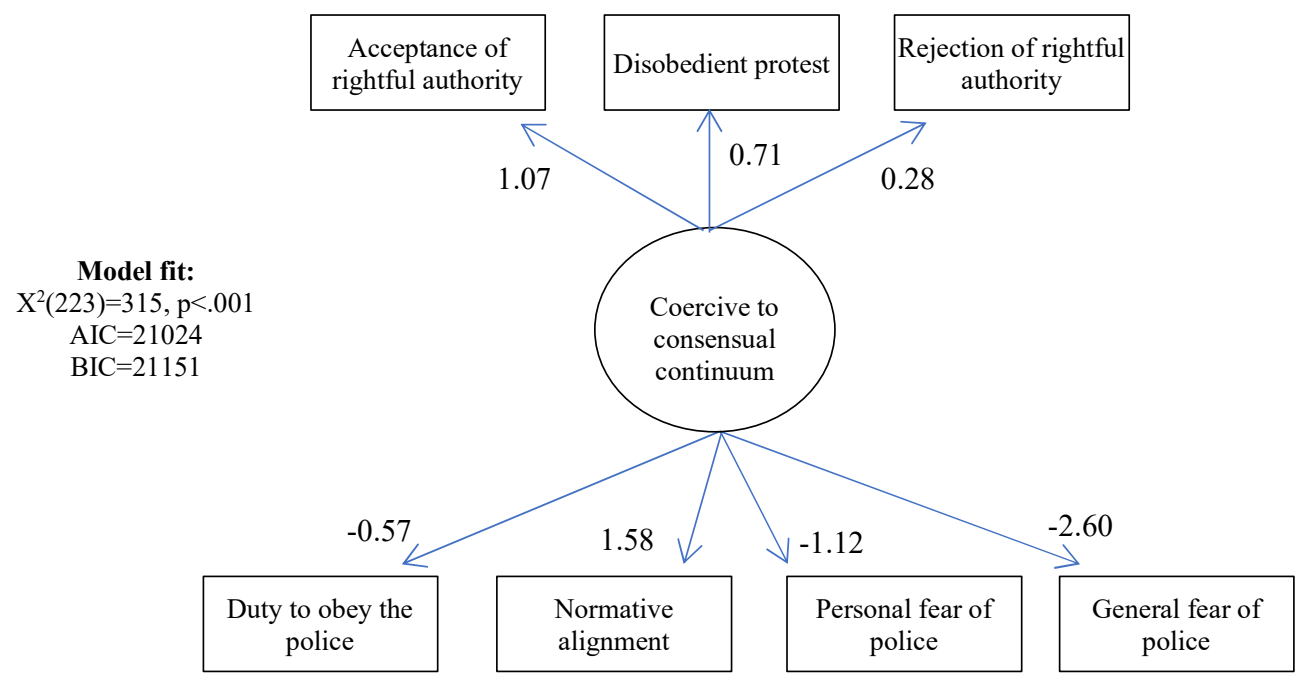

Because coercive compliance is the reference category in the LTA presented in Figure G2, the coefficients for acceptance of rightful authority, disobedient protest, and rejection of rightful authority reference category are to be interpreted as comparisons to coercive compliance. The latent trait scores for acceptance of rightful authority, disobedient protect, rejection of rightful authority and coercive compliance are (respectively): $0.124, \mathrm{SD}=0.897 ; 0.035, \mathrm{SD}=0.851 ;-0.141, \mathrm{SD}=0.804$; and -0.217 , $\mathrm{SD}=0.811$. We named it the coercive to consensual authority continuum After looking at these results, and those presented in Appendix H (which provides detailed explanation of how to interpret the nature of the underlying continuum), we named it the coercive to consensual authority continuum.

A straightforward way to compare the latent trait models is to rely on the penalised model selection criteria, the AIC (Akaike Information Criterion) and the BIC (Bayesian Information Criterion). These indices can be used to compare non-nested models, lower values, suggesting a better fit (Kuha, 2004). For both the AIC and BIC, the single-trait solution $(\mathrm{AIC}=21024.49, \mathrm{BIC}=21150.94)$ outperformed the two-trait one $(\mathrm{AIC}=22560.85, \mathrm{BIC}=22714.79)$. Combined with the significant ambivalence found in the bivariate correlations (Tables 2 and 3 of the paper), this implies that consensual and instrumental relationships with the police can be usefully reflected along the same, single dimension. 
Appendix H: Illustrating the composition of the coercive-consensual continuum

Table $\mathrm{H}$ shows how the continuum was constituted using fitted probabilities (holding all other variables constant at their mean/reference category) according to levels of fear of the police, obligation to (dis)obey the police, and normative alignment with the police, conditional on continuum placement. It is worth noting that, as with any latent trait, the mean was close to zero $(0.001)$ and the distribution was normal $(\mathrm{SD}=0.84$, Min=-2.21, $\operatorname{Max}=2.29)$.

First, levels of personal and general fear of the police were high at the -2SD (coercive) end of the continuum, low at the $+2 \mathrm{SD}$ (consensual) end of the continuum, and below the middle at the mean (the probability of being personally afraid of the police for people at the mean of the continuum is 0.21 and the probability of saying that people are 'almost always' or 'always' afraid of the police is 0.66 ). The correlation was strong for both, but a little stronger for personal fear compared to general fear.

Second, people at the -2SD (coercive) end of the continuum were likely to either feel a coercive obligation to obey the police (probability of 0.48 ) or a rejection of rightful authority, i.e. lack of normative obligation to obey the police because officers lack legitimacy (probability of 0.41). People at the $+2 \mathrm{SD}$ (consensual) end of the continuum are likely to feel an obligation to obey the police based on consent, probability of 0.73 , although there is a 0.16 probability of feeling a coercive obligation to obey the police. People at the mean of the continuum had a 0.31 probability of feeling a consensual obligation to obey the police (acceptance of rightful authority), a 0.41 probability of feeling a coercive obligation to obey the police (coercive obligation), and a 0.19 probability of rejecting rightful authority.

Third, people at the -2SD (coercive) end of the continuum were likely to feel that the police 'never' act according to what they believe is right (probability of .88). People at the $+2 \mathrm{SD}$ (consensual) end of the continuum were likely to feel that the police 'always' act according to what they believe is right (probability of .90). People at the mean of the continuum had a 0.17 probability of saying 'rarely', a 0.39 probability of saying 'sometimes' and a .22 probability of saying 'almost always.'

Table H: Fitted probabilities

\begin{tabular}{|l|c|c|c|c|}
\hline \multirow{2}{*}{ Fitted probabilities } & \multicolumn{2}{|c|}{ Personal fear of the police - Are you afraid of the police? } \\
\cline { 3 - 5 } & -2SD & 0.091 & Don't know & Yes \\
\hline \multirow{4}{*}{$\begin{array}{l}\text { Coercive-consensual } \\
\text { continuum }\end{array}$} & -1 SD & 0.297 & 0.082 & 0.827 \\
\cline { 2 - 5 } & Mean & 0.639 & 0.171 & 0.533 \\
\cline { 2 - 5 } & $+1 S D$ & 0.882 & 0.148 & 0.213 \\
\cline { 2 - 5 } & +2 SD & 0.969 & 0.058 & 0.060 \\
\hline
\end{tabular}

\begin{tabular}{|c|c|c|c|c|c|c|}
\hline \multirow{2}{*}{\multicolumn{2}{|c|}{ Fitted probabilities }} & \multicolumn{5}{|c|}{$\begin{array}{l}\text { General fear of the police - How often would you say that people are afraid of } \\
\text { the police? }\end{array}$} \\
\hline & & Never & Rarely & Sometimes & $\begin{array}{l}\text { Almost } \\
\text { always }\end{array}$ & Always \\
\hline \multirow{5}{*}{$\begin{array}{l}\text { Coercive-consensual } \\
\text { continuum }\end{array}$} & $-2 \mathrm{SD}$ & 0.008 & 0.012 & 0.060 & 0.160 & 0.760 \\
\hline & $-1 \mathrm{SD}$ & 0.020 & 0.028 & 0.127 & 0.259 & 0.567 \\
\hline & Mean & 0.046 & 0.061 & 0.230 & 0.310 & 0.352 \\
\hline & $+1 \mathrm{SD}$ & 0.105 & 0.121 & 0.325 & 0.265 & 0.184 \\
\hline & $+2 \mathrm{SD}$ & 0.221 & 0.192 & 0.334 & 0.167 & 0.085 \\
\hline
\end{tabular}

\begin{tabular}{|l|c|c|c|c|c|}
\hline \multirow{2}{*}{ Fitted probabilities } & \multicolumn{4}{|c|}{ Obligation to (dis)obey categories } \\
\cline { 3 - 6 } \multicolumn{2}{|c|}{} & $\begin{array}{c}\text { Acceptance of rightful } \\
\text { authority } \\
\text { (normative) }\end{array}$ & $\begin{array}{c}\text { Disobedient protest } \\
\text { (normative) }\end{array}$ & $\begin{array}{c}\text { Coercive obligation } \\
\text { (instrumental) }\end{array}$ & $\begin{array}{c}\text { Rejection of rightful } \\
\text { authority } \\
\text { (normative) }\end{array}$ \\
\hline \multirow{4}{*}{$\begin{array}{l}\text { Coercive- } \\
\text { consensual } \\
\text { continuum }\end{array}$} & -2 SD & 0.060 & 0.056 & 0.475 & 0.409 \\
\cline { 2 - 6 } & -1SD & 0.148 & 0.078 & 0.474 & 0.300 \\
\cline { 2 - 6 } & Mean & 0.312 & 0.094 & 0.406 & 0.189 \\
\cline { 2 - 6 } & +1SD & 0.531 & 0.091 & 0.282 & 0.096 \\
\hline
\end{tabular}

\begin{tabular}{|l|c|c|c|c|c|c|}
\hline \multirow{2}{*}{ Fitted probabilities } & \multicolumn{3}{|c|}{ Normative alignment - The police act according to what I believe is right } \\
\cline { 3 - 7 } & \multirow{2}{*}{ Never } & Rarely & Sometimes & $\begin{array}{c}\text { Almost } \\
\text { always }\end{array}$ & \multirow{2}{*}{ Always } \\
\hline \multirow{4}{*}{$\begin{array}{l}\text { Coercive-consensual } \\
\text { continuum }\end{array}$} & -2 SD & 0.878 & 0.083 & 0.032 & 0.006 & 0.002 \\
\cline { 2 - 7 } & -1 SD & 0.469 & 0.280 & 0.192 & 0.043 & 0.016 \\
\cline { 2 - 7 } & Mean & 0.098 & 0.172 & 0.390 & 0.220 & 0.119 \\
\cline { 2 - 7 } & +1 SD & 0.013 & 0.030 & 0.151 & 0.282 & 0.524 \\
\cline { 2 - 7 } & +2SD & 0.002 & 0.004 & 0.023 & 0.072 & 0.900 \\
\hline
\end{tabular}




\section{Appendix references}

Bradford, Ben, Aziz Huq, Jonathan Jackson and Ben Roberts. 2014b. "What price fairness when security is at stake?" Regulation \& Governance, 8 (2): 246-68.

Bradford, Ben, Kristina Murphy and Jonathan Jackson. 2014a. "Officers as mirrors". British Journal of Criminology, 54 (4): 527-50.

Fine, A., Beardslee, J., Mays, R., Frick, P. J., Steinberg, L. and Cauffman, E. (forthcoming). Measuring Youths' Perceptions of Police: Evidence from the Crossroads Study. Psychology, Public Policy \& Law.

Huq, Aziz Z, Jonathan Jackson and Rick J. Trinkner. 2017. "Legitimating Practices: Revisiting the Predicates of Police Legitimacy." British Journal. of Criminology, 57 (5): 1101-22.

Jackson, Jonathan, Ben Bradford, Betsy Stanko and Katrin Hohl. 2013. Just Authority? Trust in the Police in England and Wales. Oxon: Routledge.

Jackson, Jonathan, et al.. 2012. "Why do People Comply with the Law?" British Journal. of Criminology, 52 (6): 1051-71

Kuha, Jouni. 2004. "AIC and BIC: Comparisons of Assumptions and Performance." Sociological Methods \& Research, 33 (2): 188-229.

Lall, Ranjit. 2016. "How Multiple Imputation Makes a Difference.” Political Analysis 24 (4): 414-33.

Lang, Kyle M. and Wei Wu. 2017. "A Comparison of Methods for Creating Multiple Imputations of Nominal Variables." Multivariate Behavioral Research, 52 (3): 290-304.

McLean, K. (2020), 'Revisiting the Role of Distributive Justice in Tyler's Legitimacy Theory', Journal of Experimental Criminology, 16, 335-46. doi: 10.1007/s11292-019-09370-5.

Nery, Marcelo B., Altay A. L. Souza, \& Sergio Adorno. (2019). Os padrões urbano-demográficos da capital paulista. Estudos Avançados, 33 (97): 5-36.

Nylund, Karen L., Tihomir Asparouhov and Bengt O. Muthén. 2007. "Deciding on the Number of Classes in Latent Class Analysis and Growth Mixture Modeling." Structural Equation Modeling, 14 (4): 535-69.

Oliveira, Thiago R. (2021). "Violence and Coercive Policing: Dynamics and Consequences of the Overpolicing-underpolicing Paradox in Brazil's Largest City." Working paper available at SocArXiv: https://doi.org/10.31235/osf.io/89jkv.

Oliveira, Thiago R., André Rodrigues de Oliveira and Sergio Adorno. 2019. "Legitimidade da Polícia: Um Modelo de Mensuração.” Rev. Brasileira de Ciências Sociais, 34 (100): 1-25.

Oliveira, Thiago R., André Zanetic and Ariadne Lima Natal. 2020. "Preditores e Impactos da Legitimidade Policial: Testando a Teoria da Justeza Procedimental em São Paulo.” Dados Revista de Ciências Sociais, 63 (1).

Oliveira, Thiago R., André Zanetic, \& Ariadne Natal. (2020). "Preditores e impactos da legitimade policial: testando a teoria da justeza procedimental em São Paulo.” Dados - Revista de Ciências Sociais, 63 (1). https://doi.org/10.1590/001152582020197

Peterson, B. and Harrell, F.E. (1990). Partial Proportional Odds Models for Ordinal Response Variables. Journal of the Royal Statistical Society Series C, 39(2), 205-217.

Sunshine, Jason and Tom R. Tyler. 2003. "The Roles of Procedural Justice and Legitimacy in Shaping Public Support for Policing." Law \& Society Review., 37 (3): 513-48.

Trinkner, Rick, Jonathan Jackson and Tom R. Tyler. 2018. "Bounded Authority: Expanding "Appropriate" Police Behavior Beyond Procedural Justice." Law \& Human Behavior, 42 (3): 280-93.

Tyler, T. R., \& Blader, S. L. 2000. Cooperation in groups: Procedural justice, social identity, and behavioral engagement. Philadelphia, PA: Psychology Press.

Tyler, Tom R. 2006a. Why People Obey the Law. New Haven, CT: Yale University Press.

Tyler, Tom R. 2006b. "Psychological Perspectives on Legitimacy and Legitimation." Annual Review. of Psychology 57: 375-400.

Tyler, Tom R. and Jonathan Jackson. 2014. "Popular Legitimacy and the Exercise of Legal Authority." Psychology, Public Policy and Law, 20 (1): 78-95.

Von Hippel, Paul T. 2009. "How To Impute Squares, Interactions, and Other Transformed Variables." Sociological Methodology 39 (1): 265-91.

Von Platz, J. (2020). Theories of Distributive Justice: Who Gets what and why. Routledge

Williams, R. (2006). "Generalized ordered logit/partial proportional odds models for ordinal dependent variables." STATA Journal, 6 (1): 58-82. 
